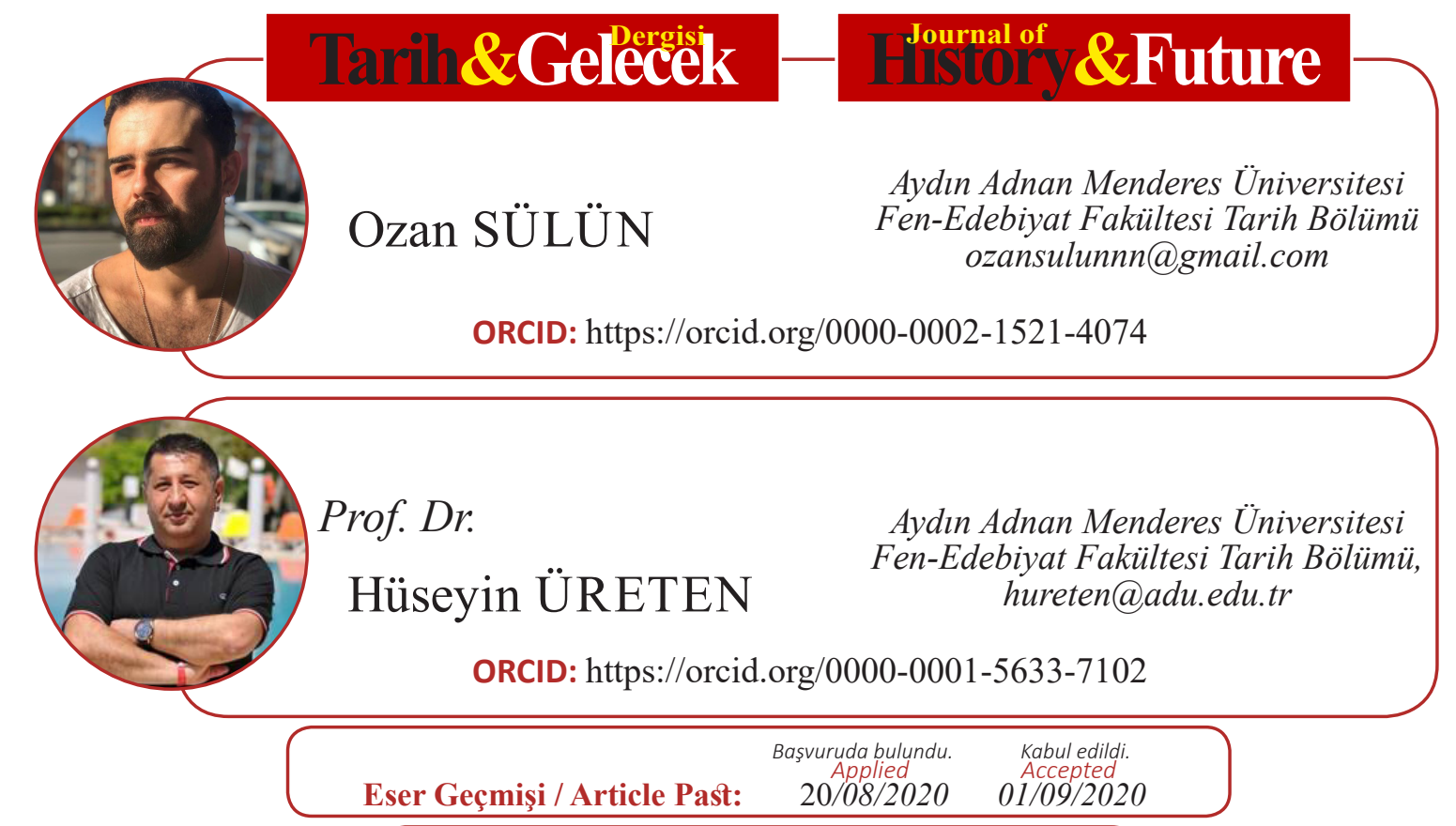

Araştırma Makalesi

DOI: http://dx.doi.org/10.21551/jhf.783116

Research Paper

Orjinal Makale / Orginal Paper

\title{
Antik Hellen ve Roma Toplumlarında Büyü ve Kehanet
}

$\ddot{\mathbf{O z}}$

\section{Magic and Divination in Ancient Greek and Roman Society}

İnsanın kendisinden üstün ve kutsal kabul ettiği varlıklarla, atacakları adımlardan önce ya da aşamalarında güvence almak, onları memnun etmek gibi çeşitli amaçlarla iletişime geçme istekleri büyülerin ortaya çıkışını sağlamıştır. Kutsal ve kendisinden üstün olan varlığa yaklaşarak sosyal yaşamı ya da devletine dair adımlarda kendisini güvende hissettirecek yorumlar almak üzere kehanet büyülerine başvurmuşlardır. Çalışmada Antik Hellen ve Roma toplumlarında sözü geçen bölgede büyü ve kehanet kavramlarının açıklanmasıyla birlikte papirolojik ve klasik kaynaklar aracılığıyla Hellenizm ile bölgedeki yerel kültürlerin senkretik yapıları incelenmiştir.

Anahtar Kelimeler: Büyü, Büyücülük, Kehanet, Apollon, Helios.

\begin{abstract}
The desire to communicate with other beings that men consider as superior and sacred, for various purposes such as assuring and pleasing them before or during the steps they will take, led to the emergence of magic. By approaching the superior and sacred beings, they approached prophetic spells to get opinions that would make them feel safe in their social life or in the steps of their state. In this study, the syncretic structures of Hellenism and local cultures in the said region were examined with the help of papyrological and classical sources together with the explanation of concepts of magic and prophecy in the region mentioned in ancient Hellenic and Roman societies.
\end{abstract}

Key Words: Magic, Magician, Divination, Apollo, Helios.

* Bu çalışma "Antik Hellen ve Roma Toplumlarında Büyü ve Kehanet" başlıklı yüksek lisans tezinden türetilmiştir ATIF: SÜLÜN Ozan, ÜRETEN Hüseyin, “Antik Hellen ve Roma Toplumlarında Büyü ve Kehanet”, Tarih ve Gelecek Dergisi, 6/3 (Eylül 2020), s. (791-817) 


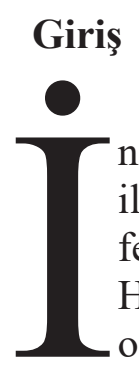

nanışın varlığ 1 ile birlikte üstün ve kutsal kabul edilen varlıklarla çeşitli amaçlarla iletişime geçme dürtüsü, büyülerin varlığına sebep olmuştur. Büyük İskender'in fetihleri ile birlikte gelişerek büyüyen Hellenizm ideolojisi ve Eskidoğu kültürleri ile Hellen kültürünün ortak yönde ilerleyişinin ardından Akdeniz Dünyası'nda egemen olan Roma İmparatorluğu sırasında da bu kültürel birleşimin devam etmesi, çalışma coğrafyasının belirlenmesinde etkin rol oynamıştır. İS 4. yüzyılda Hristiyanlık inancı ile birlikte kültürel anlamda yeni bir döneme girilmesi ve büyü belgelerinin yoğunluğu sebebiyle çalışmanın zaman sınırları İS 1.-4. yüzyıllar olarak sınırlandırılmıştır. Çalışmanın temel kaynağı, İS 1.-4. yüzyıl olarak tarihlenen ve Mısır ile Doğu Akdeniz Bölgesi'nden tespit edilerek bir araya getirilen, 1986 yılında ise yeniden kataloglanarak ortaya çıkarılan Karl Preisendanz editörlüğündeki Papyri Graecae Magicae ${ }^{1}$ isimli büyü papirüsleridir. Hellenizm ile birlikte özellikle Doğu Akdeniz olmak üzere söz konusu bölgede gelişip kullanım gören Hellen diline, diğer uygarlıklara ait olan büyü kitapları da çevrilmiştir. Dolayısıyla çalışmanın temel kaynaklarından birini oluşturan büyü papirüsleri de Hellen dilindedir. ${ }^{2}$ Daha sonra İngilizce diline çevrilerek tekrar yayımlanmıştır.

Kutsal ve üstün kabul edilen varlıklarla iletişime geçme dürtüsü, başarılı insanın başarısının devam edip etmeyeceğini, daha zorlu yaşam süren insanın ise karşılaşabileceği daha zorlu durumu ya da savaş öncesinde bulunan bir devletin sürecin ve sonucunun nasıl olacağını merak etmesi üzerine kehanet büyüleri aracılığıyla kendisini göstermektedir. Büyü kavramına genel bir açıklık getirmek gerekirse Malinowski'nin tanımı kullanılabilmektedir: Büyü, doğumu olmayan, oluşturulmayan, bir gözlem sonucu ortaya çıkmamış fakat en baştan beri insanın tamamlayıcısı olarak var olan bir olgudur ve insana dair her şey ile ilgilidir. ${ }^{3}$

\section{Antik Hellen Toplumunda Büyü ve Büyücülük}

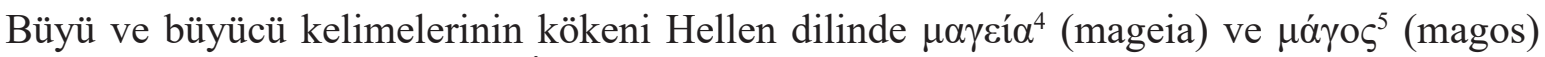
kelimelerinden ortaya çıkmaktadır. İran'ın batı bölgesinde yaşamlarını sürdüren magoslardan mageia kelimesinin geldiği varsayılmaktadır. ${ }^{6}$ Bu sözcük, ileride de değinileceği üzere İncil'de Hz. İsa'ya hediyeler ile doğudan gelen kişiler ve Eski Pers rahipleri olmak üzere iki anlamda kullanım görmektedir. ${ }^{7}$ Latince kökenine bakıldığında da Persli bilgin ve büyücü anlamları ortaya çıkmaktadır. ${ }^{8}$ Greek-English Lexicon, (New York: American Book Company, 1882), 483.

6 2003), 36.

7 Erkan İznik, “Magi, Magus ya da Magician: Rahipten Büyücüye”, Anadolu Üniversitesi Edebiyat Fakültesi Dergisi, c.1, s.3, (2005), 202.

8 Marchant and Joseph F. Charles, Cassell's Latin Dictionary: Latin-English and English-Latin, (London: Cassell Company, 1952), 330 . 
Hellenistik Dönem'e gelindiğinde yaşanan siyasi gelişmeler, Hellen kültürü ve Doğu kültürlerinin etkileşimini güçlendirmiş, çeşitli benzerlikler ortaya çıkarmıştır. Bunlardan biri de Büyük İskender'in Pers İmparatorluğu'nu ele geçirmesinin ardından Hellenli rahipler ile Batı İran bölgesinde varlıklarını sürdüren magosların tören uygulayış biçimlerinin benzerlikleridir. ${ }^{9}$

Yazıyla olan ilişkinin artması ile paralel olarak İÖ 5. yüzyılda sağlık, bağlama, aşk ve gündelik işler ile ilgili çeşitli konularda büyüye başvurular, Hellenlerde artış göstermektedir. Bu doğrultuda Hellenler, kendi tanrıları dışında Mısır, Asur, Yahudi tanrıları gibi çeşitli kültürlerin tanrılarına da başvurmuşlardır. ${ }^{10}$ Gündelik herhangi bir işle ilgili büyüye başvurmaya örnek olarak Frazer, bir çiftçinin topraklarını farelerden uzaklaştırmak için neler yapması gerektiğini aktarmaktadır. Buna göre: "Sizden rica ediyorum ey buradaki fareler, ne bana zarar verin, ne de başka bir farenin bunu yapmasına izin verin. Size öteki tarlayı (burada tarla belirtilir) veriyorum; fakat sizi burada bir daha yakalarsam, Tanrıların anası adına, yedi parçaya bölerim.” yazısı gün doğumundan önce, tarla içinde bir taşın üzerine yazı üst kısımda kalacak şekilde koyulmalıdır. ${ }^{11}$

Antik Hellen düşünürlerinin büyü ve büyücülüğün yanı sıra özellikle kehanete karşı bakış açılarına değinmek, dönemin algısında genel bir görüş sağlamaya faydalı olacaktır.

İÖ 9. yüzyılda günümüz İzmir'inde yaşadığı düşünülen Homeros, kendisinden sonra gelen Hellaslı filozoflar üzerinde bırakacağı etki nedeniyle ayrı bir yere sahiptir. ${ }^{12}$ Troia Savaşı'nın küçük bir bölümünü ele alan Ilias/Ilyada (I $\lambda$ ıás) eseri, Troia destanından çok Akhilleus'un destanı olarak değerlendirilmektedir. Akhilleus'un Akha ordularının komutanı Agamemnon'a öfkelenmesi sonucunda savaşı bırakması ile başlayan eser, Troia kahramanı olan Hektor'u öldürmesi ve cesedini babası Kral Priamos'a teslim etmesi ile son bulmaktadır. 24 bölüm 16.000'den fazla dizeden oluşan Ilyada, 51 günlük bir zaman dilimini ele almaktadır. ${ }^{13}$ Söz konusu eserde Homeros, Akhilleus'un sözleri ile birlikte Apollon'un kehanet ile olan ilişkisini de aktarmaktadır:

“...Gel bir duacıya, bir biliciye başvuralım,

Ya da bir düş yorumcusuna, bilirsin Zeus getirir düşü.

O söylesin, Phoibos Apollon'un bu büyük öfkesi neden?..."14

Devamında ise Apollon'un kehanet verme özelliğine açık şekilde değinilmektedir:

"Bunları söyleyip oturdu o, kalktı Kalkhas,

Thestor'un oğlu, düş yorumcularının en büyüğü,

9

10

11

12

13

14 Hom. Ilyada, I. 55-65. 
Biliyordu her şeyi, geçmekte olanı geçmişi, geleceği.

Phoibos Apollon verdiydi bu hüneri ona...”15

Aynı eserde kehanetin kurban yoluyla elde edilmesine atıfta bulunularak kurban ve kâhin etkileşimi de “...Kurbanları yorumlayan bir biliciden..." cümlesi ile aktarılmaktadır. ${ }^{16}$

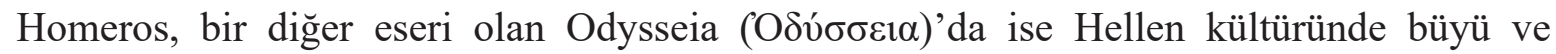
büyücülükle ilişkilendirilen Kirke'den bahsetmektedir. Bazen Güneş ile Okeanos kızı Perseis'in, bazen ise Hekate'nin kızı olarak bilinen Kirke, aynı zamanda Pasiphae'nin de kız kardeşidir. Odysseus'un arkadaşları, Aia Adası'nın ormanında Kirke'nin misafiri olması ve Kirke'nin gelen misafirleri domuza dönüştürdükleri aktarılmaktadır. ${ }^{17}$ Mitosun devamında arkadaşlarına katılmadan gözlemleyen Eurylokhos, durumdan Odysseus'u haberdar etmiş, Odysseus ise arkadaşlarını kurtarmak üzere yola koyulmuştur. Kirke'nin büyüsünden etkilenmemek için öncesinde Hermes'ten aldığ 1 moly ${ }^{18}$ bitkisini kullanmıştır. Odysseus'un Kirke'den büyülenmiş arkadaşlarını kurtarmasını Homeros eserinde aktarmaktadır. ${ }^{19}$ İÖ 5 . yüzyılda büyücü kavramının henüz yer almadığ Hellenler için Kirke bir büyücüden çok korkutucu bir tanrıça olarak yer almaktadır. ${ }^{20}$ Homeros'un aktarımlarında aynı zamanda soylu biri olarak bahsedilen Eurymosoğlu Telemos isimli ünlü bir kâhinden de bahsedilmektedir. ${ }^{21}$

Homeros gibi kendisinden sonrakileri de etkileyen İÖ 8. yüzyılda yaşamış, Korinth Körfezi'nin kuzeydoğusundaki Boeotia'nın Ascara bölgesinde doğmuş olan Hesiodos, Hellenlerde büyü ve büyücülük ile ilgili en önemli figürlerden olan Hekate'ye, "Tanrıların Doğuşu” (Theogonia $[\Theta \varepsilon$ corovía $])^{22}$ eserinde büyük rol vermiştir. Hekate diğer tanrı ve tanrıçaların aksine direkt olarak büyü ve büyücülük ile bağlantılıdır. Bu nedenle siyasi toplantılarla ilgili olarak rhetorik, spor ve savaşlarla ilişkili olarak zafer, balıkçılık ve hayvancılıkla bağlantılı olarak ise bereket vermesi ile bilinmektedir. Fakat bu bahsedilen durumlar yetki alanını kısıtlamamaktadır. Sonraki dönemlerinde ise dönüşüm göstererek yer altı dünyası ile ilişkilendirilmiş ve "büyülere hükmeden" olarak bilinmiştir. Ellerinde tuttuğu iki meşale veya köpek ya da kurt biçimlerinde büyüyü uygulayan kişiye görünmektedir. ${ }^{23}$ Hesiodos aktarımlarında Asterie'nin Hekate'nin annesi, Titan Perses'in

15 Hom. Ilyada, I. 70-75.

16 Hom. Ilyada, XXIV. 221.

17 Homeros, Odysseia, Çev. Azra Erhat ve A. Kadir, (İstanbul: Türkiye İş Bankası Kültür Yayınları, 2014), X.232-240.

18 Moly bitkisi ile ilgili Homeros'un aktarımı şu şekildedir: "Çiçeği sütbeyazdl, kökü kapkara, ona 'molü' derlerdi tanrılar

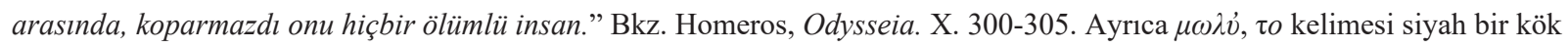
ve beyaz bir çiçeğe sahip büyülü güce sahip bitki anlamına gelmektedir. Bkz. Liddel, Scott, 1882, 523.

19 Homeros, Odysseia. X. 280-300.

20 Marcello Carastro, Yunanistan'da Büyünün İcad1, Çev. Leyla Tonguç Basmacı, Ed. Umberto Eco, Antik Yunan, (İstanbul: Alfa Basım Yayım Dağıtım, 2018), 693-694.

21 Homeros, Odysseia. IX. 508-515.

22 Hesiodos, tanrıların kaynağını dolayısıyla evrenin kaynağını açıkladığı bu eserinde her şeyden önce bir kaosun var olduğunu aktarmaktadır. Daha sonra yeryüzünü temsilen Gaia ve aşkı temsilen Eros doğmuştur. Nedenlerini açıklamadan sade bir şekilde tanrıların doğuşunu aktarmaktadır. Bkz. Cemil Sena, Filozoflar Ansiklopedisi II E-H, 417.

23 “Onuncu şafă̆ın aydınlığında Hekate, elinde bir meşale ile geldi ve haberleri verdi...” Bkz. The Homeric Hymns and Homerica, Trans. H. G. Evelyn and M. A. White, (London: William Heinemann, 1920), 291-293. 
ise babası olduğunu iletmiştir. ${ }^{24}$ Hesiodos, aynı eserinde Hekate'nin Zeus tarafından nasıl üstün tutulduğunu, kendisine nelerin bahşedildiğini ve neler yapabileceğini uzun ve övgü dolu dizelerle aktarmaktadır. ${ }^{25}$

Karia Bölgesi'nde bulunan Halikarnassos'ta İÖ 490'larda doğan ve dokuz kitaptan oluşan tarih kitabını yazan Herodotos ise Pers topluluğunda ateş rahipleri olarak görev alan magoslar hakkında bilgiler aktarmaktadır. Bu bilgilerin içerisinde en önemlilerinden biri magosların kralın danışmanı rolünde olduklarına dairdir. ${ }^{26}$ Aynı zamanda kurban törenlerinde aktif konumda oldukları, rüya yorumlayıcı olmalar ${ }^{27}$ ve daha da önemlisi kehanetten sorumlu oldukları aktarılmaktadır. ${ }^{28}$

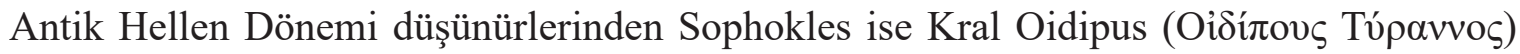
eserinde Oidipus için gerçekleşen kehanetten bahsetmektedir. ${ }^{29}$ Ayrıca kör bir kâhin olarak bilinen Teiresias'ın, Thebai Kralı Kreon'a kehaneti aktarmasından da bahsedilmektedir. ${ }^{30} \mathrm{Bu}$ sırada kehanetin kuşların gözlemlenmesi yoluyla elde edildiği de aktarılmaktadır. ${ }^{31}$

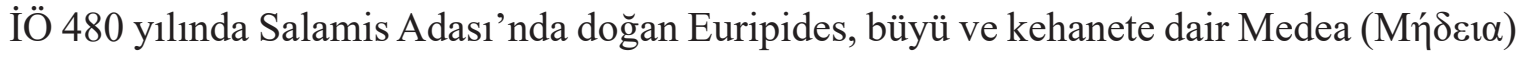
eserinde bilgiler sunmaktadır. Bu eserde, kâhin Pittheia'nın kehanet sayesinde Aegeas'ın kısırlı̆̆ını geçirmesinden bahsedilmektedir. ${ }^{32}$ Aynı zamanda kehanet merkezi olarak bilinen Delphoi’a bu

24 Hesiodos, Theogonia, Çev. Azra Erhat ve Sabahattin Eyüboğlu, (İstanbul: Türkiye İş Bankası Kültür Yayınları, 2017), 405410.

25 Hesiodos, Theogonia, 415-425. Ayrica bkz. Hesiodos, Theogonia, 430-450.

26 “... Bana bu emirleri veren adam, Cambyses 'in işlerine bakan magidir...” Bkz. Herodotos, Tarih, Çev. Müntekim Ökmen, (İstanbul: Remzi Kitapevi, 1973), III. 63.

27 Herodotos, Tarih, I. 120.

28 "Perslerin göreneklerine gelince işte bildiklerim şunlardır: Tanrı heykeli, tapınak, sunak yapmak gibi şeyler bilmezler; hatta yapanlara deli derler, bu, sanırım, onların tanrılara, Hellenler gibi insan biçimi yakıştırmış olmamalarından ileri gelir. Dinleri Zeus'a kurban kesmeyi gerektirir; kurbanları dă̆ başlarında keserler ve Zeus dedikleri de tanrıal gök kubbedir. Güneşe, aya, toprağa, ateşe, suya ve rüzgâra da kurban adarlar. Başlangıçtan beri kurban kestikleri tanrılar bunlardır, yalnız sonradan Aphrodite'e tapmayı da öğrendiler, bu da onlara Asurlulardan ve Araplardan geçmiştir... Yukarıda saydiğım tanrılara karşı saygı törenleri şöyledir: Kurban kesmek için sunak yoktur, ateş de yakmazlar. Kurbanın üzerine kutsal su saçmak, flüt, giyim kuşam, arpa tanesi gibi şeyleri bilmezler. Tanrllardan birine bir kurban kesmek isteyen kimse, kurbanı temiz bir yere götürür, başına, genellikle mersin dalından taç koyar, kurban hangi tanrı için kesiliyorsa, o tanrının adını anar. Kurban kesenin tanrısal yardımı yalnız kendisi için istemeye hakkı yoktur; bütün Persler için ve özellikle kral için dua eder; bütün Persler için dua ederken, kendisi de bunun içindedir. Sonra kurbanı parçalar, etleri pişirtir, yere yumuşak otlar, özellikle yonca serer, etleri bu yaygının üzerine koyar. O, bunları koyunca, yanında ayak duran bir Magos, tanrların soy zincirini anlatan dinsel bir hava okur. Bu dinsel hava, kendi anlattıklarına göre böyledir; din, bir Magos olmadan kurban kesmeyi yasak etmiştir. Kısa bir duruştan sonra kurbanı keser, etleri toplar ve istediği gibi yapar." Bkz. Herodotos, Tarih, I. 131-132. Magosların kehanette bulunduklarına dair bir diğer aktarım şu şekildedir: "Kyros'a gelince, daha önce anlatmış olduğum rüyasını yorumlamış olan magosları getirtti. Geldiklerinde Astyages onlara sordu, rüyasını nasıl yorumlamışlardı diye. Aynı açıklamayı yaptılar, çocuk yaşarsa ve daha önce ölmezse er geç başa geçecektir..." Bkz. Herodotos, Tarih, I. 120.

29 Sophokles, Kral Oidipus, Çev. Bedrettin Tuncel, (İstanbul: Milli Eğitim Bakanlığı Yayınları, 1992), 14-15.

30 Sophokles, Antigone, Çev. Ari Çokona, (İstanbul: Türkiye İş Bankası Kültür Yayınları, 2017), 5. 991-1023.

31 Kuşların gözlemlenmesi aracılığıyla kehanet elde etme sanatı yaygın olarak Antik Roma toplumunda da kullanılmaktadır. Bu ritüelleri aristokrat kesimden seçilmiş olan rahipler uygulamaktadır. Bkz., Charles Freeman, Mısır, Yunan ve Roma, Çev. Suat Kemal Ang1, (Ankara: Dost Kitabevi Yayınları, 2003), 364.

32 Pierre Grimal, Mitoloji Sözlüğ̈̈ Yunan ve Roma, Çev. Sevgi Tamgüç, (İstanbul: Kabalcı Yayınevi, 2012 ), 766. 
sebeple başvurmasına da değinilmektedir. ${ }^{33}$ Eserde de kendisine yer bulan Medea, tıpkı Hekate gibi Hellen büyü dünyasında başlıca büyücüler arasında bulunmaktadır. Medea için Helios'un soyundan geldiği söylenmektedir. ${ }^{34}$

Aegeas'ın kısırlığına şifa getirmesi gibi iyileştirici yönleri ile de kullanıma açık olan büyülere dair bir diğer önemli örnek, İÖ 460 yılında Kos’ta doğduğu düşünülen Hippokrates tarafından verilmektedir. Büyü ile tıp arasındaki ilişki, özellikle iki hastalık çerçevesinde önem göstermektedir. Bunlardan biri doğa üstü güçlerle ilişkisi olduğuna inanılan akıl rahatsılıkları, diğeri ise "kutsal hastalık" olarak anılan ve ruhun ele geçirildiği düşünülen epilepsidir. Özellikle İÖ 5. yüzyılda büyüler aracılığıyla hastalıkları iyileştirmenin yoğunlaşması, doğru oranda bu duruma gelen eleştirilerin artmasına da sebep olmuştur. Bu doğrultuda aynı yüzyıl içerisinde Hippokrates

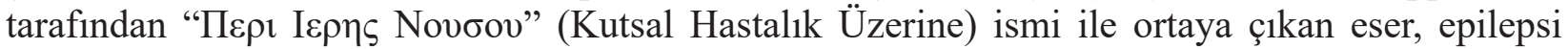
konusu bağlamında büyüye yapılan ilk eleștirilerden biridir. ${ }^{35}$

Yazarlık dışında filozof ve komutan sıfatları ile de anılan Ksenophon'un yaşamında ise kehanete dair izlere rastlanılmaktadır. Kehanet Merkezi olarak Delphoi, Ksenophon'un Kyros ile

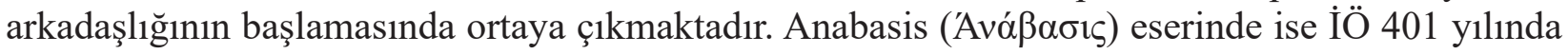
Kral Artakserkses'e karşı sefer öncesi kehanete danışıldığından bahsedilmektedir. ${ }^{36}$ Ksenophon, önceki düşünürler gibi magosların Pers topluluğuna ait dini bir grubu ifade ettiğini ${ }^{37}$ ve kurban törenlerinde yer aldıklarını da aktarmaktadır. ${ }^{38}$

Ksenophon'un kehanete dair bir diğer aktarımı ise babası ile birlikte savaş yolculuğunda bulunan Kyros'a verilen ögütte bulunmaktadır. Göğün gürleyişinin tanrıların yardımcı olacağ1 yönünde yorumlanması ve babası tarafından Kyros'a verilen öğütten de açıkça görülüyor ki kehanetten yalnızca savaş öncesinde değil savaş sırasında da yararlanılmaktadır: "Sevgili oğlum! Gökyüzünden aldığımız alametlerden anlaşıldığına göre tanrılarımız size yardımcı olacaklar. Bundan eminiz. Çünkü sizlere buna uygun bir eğitim verildi. İnsanların tanrıların dertlerini anlayabilmek ve onların gücünü hissedebilmek için gözlere ya da kulaklara ihtiyacı yoktur. Öte yandan tanrılardan söz eden hilekârlar ise sizi her zaman aldatmak üzere hazır bulunmaktadırlar. Yanınızda bir falcı olmadığı zamanlarda göksel işaretleri yorumlamaktan aciz kalmamalısınız. Falcılık sanatını kendin icra ederek tanrıların arzularını anlayabilirsin." 39

Herodotos ve Ksenophon gibi magosların Perslere ait dini bir sınıfa ait olduklarını ve ritüellerde aktif olarak görev aldıklarını aktaran bir diğer Antik Hellen düşünürü Platon, "Devlet” (Politeia $[\Pi о \lambda \imath \tau \varepsilon \iota \alpha])$ isimli eserinde sözü geçen sınıf için “...Tanrıları kendilerine hizmet etmeye kandırır,

33 Euripides, Medea, Çev. Ari Çokona, (İstanbul: Türkiye İş Bankası Kültür Yayınları, 2018), 665-675.

34 Medea’ya dair daha ayrıntılı bilgiler için bkz. Pierre Grimal, Mitoloji Sözlüğü Yunan ve Roma, 462-464.

35 Antonio Clericuzio, Yunanistan'da Büyü ve Kehanet. Çev. Leyla Tonguç Basmacı, Ed. Umberto Eco, Antik Yunan, (İstanbul: Alfa Basım Yayım Dağıtım, 2018), 1097-1098.

36 Ksenophon, Anabasis, Çev. Oğuz Yarlıgaş, (İstanbul: Kabalcı Yayınevi, 2011), III. 1. 5-8.

37 Ksenophon, Cyropedia, Trans. Walter Miller, (Cambridge: Harvard University Press), IV. 13. 5.

38 Ksenophon, Cyropedia, VIII. 1.21.

39 Ksenophon, Cyropedia, I. 6. 2. 
doğruyu da eğriyi de kötülük edebilirler..." sözleriyle eleştirilerde bulunmaktadır. ${ }^{40}$ Din üzerine temel düşüncesi insanların tanrılara boyun eğmesi gerektiği yönündedir. Fakat Platon'a göre büyücüler tam tersini yaparak tanrıları kontrol etmeye çalışmaktadır. Büyü ve büyücülüğe karşı katı bir tutum sergileyen Platon, büyücülerin ritüellerinin resmî din ile paralellik sergilemesinden dolayı polis açısından bu durumu tehlikeli olarak nitelendirmiş ve büyücülüğe dair ceza olarak idamı savunmuştur. ${ }^{41}$ Yasalar (Nohoí) eserinde de büyücüler hakkındaki düşüncelerinin yanı sıra cezalandırmalarına dair de ifadesi bulunmaktadır. ${ }^{42}$

\section{Antik Roma Toplumunda Büyü ve Büyücülük}

Magosların Hellenlere göre Roma'daki görevleri çok daha farklı etkilere sebep olmaktadır. Hellenistik Dönem'de Hellenlerle birlikte yaşamlarını sürdüren magoslar, İS 1. yüzyılda Roma'ya gelmişlerdir. Armenia Kralı Tiridates ile birlikte Roma'ya geldiklerinde magos rahipleri dini görevlerinin yanı sıra büyücü ve gökbilimci olarak bilinmişlerdir. Büyücü sıfatını daha sonra edinen magosların İncil'de gökbilimci olarak yer almalar1 ${ }^{43}$ ise doğudan batıya süren yolculuklarında Babil'de astronomi ve astroloji ile karşı karşıya kalmaları ile açıklanabilmektedir. Bu durum sonucunda Zodyak işaretleri ve gezegen sembollerini beraberlerinde batıya getirmeleri, Roma'da büyücülük konusunda büyük etki göstermiştir. ${ }^{44}$

Büyük değişimlere yol açacak Hristiyanlığın doğuşu ve gelişimi, magoslara da etki etmiş, önceden de bahsedildiği üzere magoslar için artık iki durum teşkil etmiştir. Bunlar Hristiyanlığın ilk yıllarında "Gökbilimci olan doğulular", sonraları ise "büyücüler"dir. Magosların tamamıyla ve kesin biçimde büyücü olarak nitelendirilmeleri de bu şekilde olmuştur. ${ }^{45}$ Antik Hellen düşünürlerinde olduğu gibi Antik Latin düşünürlerinin de büyü ve büyücülükle ilgili çeşitli aktarımları bulunmaktadır.

40 Platon. Devlet, Çev. Sabahattin Eyüboğlu ve M. Ali Cimcoz, (İstanbul: Türkiye İş Bankası Kültür Yayınları, 2013), II. 364a.

41 Antonio Clericuzio, Yunanistan'da Büyü ve Kehanet, 1096.

42 “Tanrılara inanmamaktan, ilgisiz olduklarını ya da kandırllabildiklerini düşünmekten öte, bir de insanlıktan çıkanlar vardır ki, bunlar insanları küçümseyerek, ölülerin ruhunu çağırdıklarını ileri sürerek, kurban, dua ve büyülerle kandırarak tanrıları ikna edeceklerini vaat ederek yaşayanlardan birçoğunun aklını çelerler, para kazanma hırsıly kişileri, evleri ve kentleri temelinden yıkmaya yeltenirler. İşte bunlardan biri suçlu bulunursa, mahkeme onu yasa uyarınca içerideki cezaevinde hapis cezasına çarptırsın, hiçbir özgür kişi ona yaklaşmasın, yasa bekçilerinin saptadı̆̆ yiyeceğini kölelerden alsın. Öldükten sonra da gömülmeden ülke sinırlarının dışına atılsın; özgür bir kişi onu gömmeye kalkışırsa, isteyen onu dinsizlikten mahkemeye versin." Bkz. Platon, Yasalar, Çev. Saffet Babür, (İstanbul: Kabalcı Yayınları, 1998), X. 909b.

43 “İsa'nın Kral Hirodes devrinde Yahudiye’nin Beytlehem Kenti’nde doğmasından sonra bazı yıldızbilimciler doğudan Jerusalem'e gelip şöyle dediler: 'Yahudilerin Kralı olarak doğan çocuk nerede? Doğuda O'nun yıldızını gördük ve O'na tapınmaya geldik.' Kral Hirodes bunu duyunca kendisi de bütün Jerusalem halkı da tedirgin oldu. Bütün başkâhinleri ve halkın din bilginlerini toplayarak onlara Mesih'in nerede doğacağını sordu. 'Yahudiye'nin Beytlehem Kenti'nde' dediler. Çünkü peygamber aracılı̆̆ıyla şöyle yazılmıştır: 'Ey sen, Yahuda'daki Beytlehem, Yahuda önderleri arasında hiç de en önemsizi değilsin! Çünkü halkım Ísrail'i güdecek önder senden çıkacak.' Bunun üzerine Hirodes yıldızbilimcileri gizlice çağırıp onlardan yıldızın göründüğ̈̈ anı tam olarak öğrendi. 'Gidin, çocuğu dikkatle arayın, bulunca bana haber verin, ben de gelip O’na tapınayım' diyerek onları Beytlehem 'e gönderdi. Yıldızbilimciler, kralı dinledikten sonra yola çıktılar. Doğuda görmüşs oldukları yıldız onlara yol gösteriyordu, çocuğun bulunduğu yerin üzerine varınca durdu. Yıldızı gördüklerinde olağanüstü bir sevinç duydular. Eve girip çocuğu annesi Meryem ile birlikte görünce yere kapanarak O’na tapındılar.” Bkz. Matta, 2:1-12.

44 Erkan İznik, "Magi, Magus ya da Magician: Rahipten Büyücüye”, 212-213.

45 Erkan İznik, "Magi, Magus ya da Magician: Rahipten Büyücüye”, 216. 
Büyü ve büyücü kavramlarını eserlerinde geçiren ve magos kelimesini Persli rahiplerle bağlantılı olarak kullanan Romalı ilk antik yazar İÖ 106 doğumlu Cicero'dur. "Yasalar Üzerine" (De Legibus) kitabında söz konusu terimi Hellenlerin tapınaklarının yakılmasını aktarırken kullanmaktadır. Cicero'nun aktarımına göre tapınakları yakanlar magoslardır. ${ }^{46}$ Aynı eserde kehanete dair ise kuşların gözlemlenmesi yöntemiyle ilgili bilgiler sunmaktadır. ${ }^{47}$

Büyü ve büyücülüğün yanı sıra kâhinlere de eleştiri getirdiği düşünceleri ise "Tanrıların Doğası" (De Natura Deorum) isimli eserinde bulunmaktadır: "Sırada kehanet dediğiniz öğretiniz var. Sizleri dinleseydik, bu öğreti yüzünden öyle çok batıl inançların pençesine düşerdik ki, kâhinlere, falcılara, bilicilere, gaipten haber verenlere ve rüya yorumcularına tapardık mutlaka." ${ }^{38}$

İÖ 84'te doğan Catullus, magosları aşağılayıcı söylemlerle birlikte Perslerle ilişkilendirmiş ${ }^{49}$, Romalı şair Vergilius ise Cumae Sibyllerinin ${ }^{50}$ Aeneas için verdikleri kehaneti ve sonrasını Aeneas (Aivé́as) destanında aktarmıştır. ${ }^{11}$ Sonraları ise Seneca, büyücü figür olması ile oldukça ünlü olan Medea'yı aynı isimli eserinde anlatmaktadır. Seneca'nın büyücülüğe dair aktarımlarından en önemlisi ise On İki Levha Kanunları'nda (Lat. Leges Duodecim Tabularum) büyüye dair yasanın olduğunu bildirmesidir. Roma Cumhuriyet Dönemi'nde büyü ile ilgili mageia ve magos kelimeleri dışında carmen ve excantare terimleri de kullanılmaktadır. Seneca'nın aktarımına göre On İki Levha Kanunları'nda da bu terimler geçmektedir: “Roma'da, On İki Levha Kanunları bir uyarıda bulunmaktadır: 'Kimse komşusunun hasadını büyü ile almayacak."

Antik Roma düşüncesinde büyü ve büyücülüğe dair önemli bilgi içeren bir diğer isim ise Apuleius'tur. Apuleius, farklı bir yaklaşım sergileyerek büyüleri iyi ve kötü olarak ayırmış, iyi amaç gözeterek yapılan büyülerin suç olarak değerlendirilmemesi gerektiğini, cezalandırılmasına gerek olmadığını düşünmüştür. ${ }^{53}$

Roma İmparatorluğu'na yayılmış durumda olan büyü papirüslerinin Augustus'un İÖ 13

46 “Kentlerde tapınaklar olması gerektiğini düşünüyor ve Pers din adamlarına katılmıyorum. Kserkses'in, onlara danışarak, kendilerine her yerin açık ve serbest olmasının gerektiği ve bu evrenin tamamının kendileri için bir tapınak ve ocak olduğu, tanrıları duvarlar ardına kapattıkları gerekçesiyle Hellas 'taki tapınakları yaktırdığı söylenir." Cicero, Yasalar Üzerine. Çev. Cengiz Çevik, (İstanbul: Türkiye İş Bankası Kültür Yayınları, 2016), 46.

47 Cicero, Yasalar Üzerine, 48-50.

48 Cicero, Tanrıların Doğası. Çev. Çiğdem Menzilcioğlu, (İstanbul: Kabalcı Yayınevi, 2012) I-56.

49 Catullus, The Carmina of Gaius Valerius Catullus, Trans. Leonard Charles Smithers, (London, 1894), 90.

50 Sibyller Apollon'a bağlı kâhin kadınlardır.

51 Vergilius, Aeneis. Çev. Türkan Uzel, (Ankara: Öteki Yayınevi), VI. 240-260.

52 "Et apud nos in XII tabulis cavetur NE QVIS ALIENOS FRVCTVS EXCANTASSIT". Bkz. Fritz Graf, Magic in the Ancient World. Trans. Franklin Philip, (London: Harvard University Press, 1997), 41.

53 "Bu kadarl yeter! Dikkatinizi başka bir noktaya vermenizi istiyorum. Ya ben balıklarda güçlü ilaçlar için araştırma yapmak gibi tıpta bazı özelliklere sahipsem ve bunlarla ilgileniyorsam? Tarafsı bir cömertliğe sahip doğa, tüm diğer yaratılmışseyler aracılığlyla pek çok ilaç dağıtmış ve işlemiştir, aynı şekilde benzer ilaçlar balıkta da bulunabilir. Şimdi, bir büyücünün, bir doktorun ya da büyücünün işi bu ilaçları arayıp bilmek değil midir? Filozoflar bunlardan kendi servetlerine para kazanmaz ancak kendi takipçilerine yardım edebilir. Eskinin doktorları da büyülü şarkılar ile yarayı nasıl iyileştireceklerini bilirdi, örneğin Homeros, eski yazarların en kalıcısı bize Odysseus'un yarasından çıkan kanın ilahiyle nasıl durdurulabildiğini anlatır. Şimdi, hayatı kurtarmak için yapılmış hiçbir şey bir suçlama konusu değildir." Apuleius, The Apologia and Florida of Apuleius of Madaura, Trans. H. E. Butler, (Oxford: Clarendon Press, 1909), 40. 1-10. 
yılında verdiği emirle 2000'e yakın büyü parşömeninin yakılmass ${ }^{54}$, Ephesos'ta yer alan büyü kitaplarının yakılmas ${ }^{55}$ gibi çeşitli imha işlemlerine uğradıkları bilinmektedir.

\section{Kâhinler ve Kehanet Merkezleri}

\subsection{Kâhinler}

Bir eylemi gerçekleştirmeden önce ya da aşamalarında, yapılacak ya da yapılan eylemin tanrı ya da tanrıçaların öfkesini çekip çekmeyeceğini, sonucunun başarılı olup olmayacağını öğrenmek adına kehanete başvurmak için kâhinler kullanılmaktadır. Kâhinlerin cevabı kesin bir yorum içermese de fikir sahibi olunmasını sağlamaktadır. ${ }^{56}$

Kâhinlere bireysel başvuru dışında şehirler tarafından da başvuru yapılabilmektedir. Burada dikkat edilmesi gereken durum amaçtır. Kehanetin amacı gelecek olanı öğrenmek değil, alınan kararlar ya da sonuçlara dair tanrı ya da tanrıçaların isteklerini öğrenmektir. ${ }^{57}$

Bir diğer önemli nokta ise kehanetin kesin bir sonuç vermediği durumudur. Sonuç her durumda tanrı ya da tanrıçaların isteklerine tabidir. Olumlu elde edilen bir kehanete rağmen öngörülemeyen sonuçlarla karşılaşılması ise atılacak yanlış bir adıma, yanlış yorumlamaya bağlanmaktadır. $\mathrm{Bu}$ durumla ilgili olarak Cicero, tahmin edilen sonuçların alınmamasının, kehanetin var olmadığını göstermeyeceğini bir başka örnekle desteklemektedir. Cicero’ya göre hastaların iyileşmemesi, hekimlik sanatının var olmadığını göstermiyorsa, kehanet için de aynı durum geçerlidir. ${ }^{58}$

Kehanetin yorumlanması sırasında kehanet elde edilmek istenen konudan bağımsız şekilde gelişen herhangi bir olay, kâhin tarafından işaret olarak kabul edilerek yorumlanabilmektedir.

54 Suetonius, bu emri şu sözlerle aktarmaktadır: "Lepidus'un sağlığında hiçbir zaman elinden almaya kalklşmadı̆̆ başrahipliği onun ölümü üzerine üstlendikten sonra, hiç işe yaramayan ya da değeri çok az olan ve halk arasinda dolaşan Latince ve Hellence yazılmış kehanet kitaplarından kaç tane varsa -sayıları iki binin üzerinde- her yandan toplatıp yaktırdı ve yalnızca Sibyll kitaplarını tuttu, bunları da ayıkladı ve Palatium'da Apollon heykelinin altındaki altın kaplamalı iki dolaba koydu." Bkz. Suetonius, On İki Caesar'ın Yaşamı, Çev. Fafo Telatar ve Gül Özaktürk, (Ankara: Türk Tarih Kurumu Yayınları, 2008), Aug. XXXI. 1.

55 İncil'de bu duruma ilişkin şu bilgiler bulunmaktadır: "Büyücülükle uğraşmış bir sürü kişi de kitaplarını toplayıp herkesin önünde yaktılar. Kitapların değerini hesapladıklarında toplam elli bin gümüş tuttuğunu gördüler.” Bkz. Elçilerin İşleri, 19:19.

56 Charles Freeman, Misir, Yunan ve Roma, 228.

57 Marcello Carastro, Hareketlerden Sözlere Ritüel Temelli Adetler, Çev. Leyla Tonguç Basmacı, Ed. Umberto Eco, Antik Yunan, (İstanbul: Alfa Basım Yayım Dağıtım, 2018), 610.

58 "Gözlerinin önünde aynı türden bir sürü örnek bulunan insan hiç tanrlların varlı̆̆ını kabul etmemezlik edebilir mi? Çünkü tanrıları yorumlayanlar varsa, kendileri de mutlaka var olmak zorundadır; tanrıları yorumlayan kimseler vardır; o hâlde tanrıların da var olduğunu kabul etmek zorundayız. Evet, belki tahmin edilen şeylerin hepsi gerçekleşmeyebilir. Ama bütün hastalar iyileşmiyor diye, hekimlik sanatı diye bir şeyin olmadığını söyleyemeyiz ki. Tanrılar bize gelecekteki olayların işaretlerini gösterir; insanların bu işaretleri yanlış yorumlamasının günahı tanrıların doğasına değil de insanların çıkarımlarına mâl edilir.” Bkz. Cicero Tanrlların Doğası. II. 12-13. 
Birden gelen hapşırma, beklenmedik bir ses ya da doğa olayları bunlardan bazılarıdır. ${ }^{59}$

\subsubsection{Ordu Kâhinleri}

Kâhinleri görev aldıkları alanlara göre sınıflandırmak gerekirse, belki de en önemlilerinden birini ordu kâhinleri oluşturmaktadır. Büyücülerin, Roma Generali Marius'un önderliğinde yapılan seferleri, Spartacus'un liderlik ettiği Roma'ya karşı gerçekleştirilen büyük köle isyanları örneklerinde olduğu gibi siyasi liderler ile bağlantılı konumları bu noktada önem teşkil etmektedir. Özellikle Büyük İskender'e eşlik eden Syrialı kadın kâhinin elde ettiği ayrıcalıklar önemlidir. ${ }^{60}$

Ordu kâhinlerinin görevleri manevi destek ile sınırlı değildir. Savaş stratejilerinde dahi belirleyici olabilmektedirler. Ordu kâhinlerinin nüfuzu Homeros ile başlamış, Atina'da demokrasi ile birlikte paralel olarak artış göstermiş̧ir. Aynı zamanda Hellen ordularında kâhinlere danışmadan eylemde bulunan komutan bulunmamaktadır. Komutanların yönetim kuruluna her y1l atanan kâhinler, Atina Meclisi'nin her toplantısında da bulunmaktadırlar. ${ }^{61}$ Cicero bu katılıma dair "De Divinatione" eserinde bilgiler aktarmıştır. ${ }^{62}$

Ordu kâhinleri, kehaneti elde edebilmek için çoğunlukla kurban aracılı̆̆ını kullanmışlardır. Kurban yoluyla kehanete ulaşmak iki biçimde gerçekleşmektedir. Bunlar kamp bölgesinde gerçekleştirilen kurban, yani hiera, diğeri ise savaş alanında gerçekleştirilen kurban, yani sphagiadır. Kurban hayvanının kesilmesi sonucunda kâhinin karaciğerin hareketlerini ve seğirme durumunu incelemesi komutanın eşliğinde gerçekleşmektedir. Organ durumu dışında kurban hayvanının hareketleri ve kanın akış şekli de savaşa dair onay niteliği taşımaktadır. Hiera çoğunlukla koyunken, sphagia ise dişi keçi olarak seçilmektedir. ${ }^{63}$

Ordu kâhinine sahip olmak öylesine önemli bir durumdur ki Herodotos'un aktarımlarından öğrenildiği üzere bu doğrultuda kâhinlere yurttaşlık hakkına kadar pek çok taviz verilmiştir. ${ }^{64} \mathrm{Bu}$ durum ve savaş öncesinde ya da sırasında kâhinlerin konumunu tehlikeli bulan ve komutan ile arasındaki güç ilişkisine değinen Platon, kâhinin komutanı değil, komutanın kâhini komuta etmesi gerektiğini savunmuştur. ${ }^{65}$

59 Walter Burkert, Greek Religion, Trans. John Raffan, (Oxford: Blackwell Publishers, 1985), 112.

60 Matthew W. Dickie, Magic and Magicians in the Greco-Roman World, 108.

61 Ayşen Sina, Antik Yunan'da Ordu Kâhinleri. Cedrus, c. (VII). (2019), 196-198.

62 "Hangi kral ya da halk kâhin görevlendirmemiştir ki? Yalnızca barlşın hâkim olduğu zamanlardan bahsetmiyorum, daha çok savaşın var olduğu dönemlerden, güvenliği sağlamak için yapılan savaşlardan bahsediyorum. Kendi vatandaşlarımızı geçelim, yabancı ulusların uygulamalarına bakalım. Örneğin Atinalılar, her mecliste mantis denilen belirli kâhinleri vardır. Spartalılar, adlî danışman olarak krala augurlar atarlar ve Yaşlılar Meclislerinde de augurun bulunmasını uygun bulurlar. Tehdit edici durumlar karşısında Delphoi'daki kehanete başvururlar." Bkz. Cicero, De Divinatione, Trans. William Armistead Falconer, (Loeb Classical Library, 1923), I. 43, 95.

63 Ayşen Sina, Antik Yunan'da Ordu Kâhinleri, 199.

64 Herodotos, Tarih, IX. 33-36.

65 "Sokrates: Lakhes ile ben, bilimin çeşitli konuları ele alınırsa, geçmişin nasıl olduğunu, şimdiki zamanın nasıl olduğunu ve henüz olmamışın nasıl olması gerektiğini, nasıl olacağını bilen ayrı ayrı bilimler bulunmadı̆̆ına; bu konuların hepsini, aynı bilimin bildiğine inanıyoruz. Söz gelişi, sağllk konusunda, bütün çağlar için hem olanı, hem olmuşu, hem de olacak olanı ve 
Kâhinlerin onayının alınmadan harekete geçilmediğine dair Antik Dönem yazarlarından çeşitli bilgiler bulunmaktadır. Herodotos, İÖ 490'da Marathon Savaşı'nda ${ }^{66}$, Thukydides, İÖ 415 'de Syrakusai Savaşı'nda ${ }^{67}$ ve İÖ 424 yılında Delion Savaşı'nda ${ }^{68}$ kurban aracılığıyla kâhinden gelecek onayın olmadan harekete geçilemeyeceğini aktarmıştır.

Ordu kâhinleri ile ilgili önem arz eden durum, kehanetin yorumunun olumlu olmasının, zaferi taahhüt etmeyişidir. Savaş sırasında, öncesinde ya da barış aşamasında komutanın ya da ordunun yapacağı hatalı bir hamle, gelen olumlu kehanete rağmen süreci başarısılıkla sonuçlandırabilmektedir. Kehanet aracılığıyla yalnızca tanrı ve tanrıçaların istekleriöğgrenilmektedir. Süreç sonunda elde edilecek sonuç, yapılacak doğru hamlelere bağlı kalmaya devam etmektedir. ${ }^{69}$

\subsubsection{Sibyller}

Apollon kültüne bağlı olan ve kehanette bulunmak üzere Anadolu'daki kehanet merkezlerinde görev alan kadın kâhinlere Sibyll ismi verilmektedir. Bu isim sonraları Güney İtalya'daki Cumae şehrindeki Cumae kâhinleri için kullanılmıştır. ${ }^{70}$ İlk Sibyll'in kim olduğuna dair iki görüş mevcuttur. Bunlardan biri Troialı Dardanos ile Neso'nun kızıdır. Bir diğer düşünce ise ilk Sibyll'in Lamia'nın olduğuna dairdir. İkinci Sibyll olarak ise ölümlü bir baba ile nympha ${ }^{71}$ k1z1 olan Herophile' dir. ${ }^{72}$

Hellen Sibylleri içerisinde en ünlüsü Erythraili (Lydia'da) Sibyll'dir. Korykos Dağı'nda doğduktan hemen sonra hızlı bir şekilde büyümüş ve kehanetlerine başlamış söz konusu Sibyll'in annesi nympha iken babası ise Theodoros'tur. Yaşamının 110 yıl sürdügüne dair söylentiler bulunmaktadir. $^{73}$

Sibyllere dair bahsedilmesi gereken bir diğer önemli nokta ise Sibyll kitaplarıdır. Kitapların önemi, Roma Devleti'nin kehanet ile ilişkisinde büyük bir rol oynamasından dolayıdır. Roma

nasıl olacağını bilen tek bir bilim vardır: Hekimlik. Toprak ürünleri konusunda da çiftçiliğin durumu aynıdır. Aynı şekilde savaşla ilgili konularda da komutanın bilgisinin her şeyi, özellikle olacak olanı kavradı̆̆ını; kehanete boyun eğmek bir yana, savaşta olanı ve olacak olanı bildiğinden ona egemen olduğunu, siz de onaylarsınız her halde; yasalar da kâhinin komutanı değil, komutanın kâhini kumanda edeceğini söyler. Bunu doğrulayabilir miyiz Lakhes?” Bkz. Platon, Laches, Protagoras, Meno, Euthydemus, Trans. Walter Rangeley Maitland Lamb, (London: Harvard University Press, 1962), 198d.

66 "Saflar kurulup, kesilen kurbanlardan da iyi belirtiler alınınca Atinalılar atıldılar ve hemen barbarlara karşı koşmaya başladılar.” Bkz. Herodotos, Tarih, VI. 112.

67 "Savaşı okçular ve sapancılar başlatmıştı. Bundan sonra her savaşta olduğu gibi hafif piyadeler kaçmaya başladı. Ardından kurbanlar kesildi. En sonunda da borazanlarla hoplitlere saldırl emri verildi.” Bkz. Thukydides, Peloponnesian War, Trans. Thomas Hobbes, (London: Bohn, 1843), VI. 69.

68 "O tanrlya ve kurbanlara güvenelim." Bkz. Thukydides, Peloponnesian War, IV. 92.

69 Ayşen Sina, Antik Yunan'da Ordu Kâhinleri, 200.

70 Azra Erhat, Mitoloji Sözlüğ̈̈, (İstanbul: Remzi Kitapevi, 1996), 270.

71 Nympha: Tarlaların, ve doğanın dişi perileridirler ve bunların bereketlerini sembolize eden, kırlar ve ormanlarda yaşayan "genç kadınlar” olarak tasvir edilirler. Bkz., Pierre Grimal, Mitoloji Sözlüğ̈̈̈, 533.

72 Pierre Grimal, Mitoloji Sözlüğü, 713.

73 Pierre Grimal, Mitoloji Sözlüğü, 714. 
siyasetinde yöneticilerin Capitolium Tepesi'nde bulunan bu kitaplara danıştıkları bilinmektedir. Kitaplar ilk olarak Kral Tarquinius ${ }^{74}$ tarafından satın alınmıştır. Kitapları önemli kılan bir diğer nokta ise özellikle İÖ 3. yüzyılda Roma’ya Hellen inanç sisteminden yeni tanrı ve tanrıçaların tanıtılmasını sağlamasıdır. ${ }^{75}$

\subsection{Kehanet Alma Yöntemleri}

Kehanete ulaşmak için kullanılan kurban kanından ya da kutsal sudan içmek, ateş ve dumanların şekillerini izlemek, defne yaprağı çiğnemek ve hatta tanrılar ile cinsel ilişkiye girmek gibi çeşitli yollar bulunmaktadır. ${ }^{76}$ Fakat bu yöntemlerden kuşlar, kurban ve rüyaların gözlemlenmesi yoluyla kehanete ulaşmak başlıca yollardandır.

\subsubsection{Kurban Yoluyla Kehanet Alma}

Kehanet elde etmek amacıyla kurban hayvanının iç organlarını incelemek yaygın bir gelenektir. $\mathrm{Bu}$ yöntem ile kehaneti yorumlayan kişilere haruspex denmektedir. Haruspexlerin kehanete dair yorumlarına ise extispicium denir. Bu kelime "iç organlar" anlamına gelen exta ve "bakmak" anlamına gelen scipio kelimelerinden türemiştir. ${ }^{77}$ Kurban yoluyla kehanete ulaşmanın Hellenlere Mısırlılardan geçtiği Herodotos tarafından aktarılmaktadır. ${ }^{78}$

Kurban aracılığıyla kehanet elde edilirken dikkat edilmesi gerekilen belirli durumlar mevcuttur. Bunlardan biri ve en sık rastlananı ise kurbanın karaciğerini incelemektir. Örneğin karaciğerde bir lobun eksik olması kötüye işaret olarak değerlendirilmektedir. ${ }^{79}$ Aynı zamanda böbrek, mide gibi başka organların da şekil ve renk gibi çeşitli durumları da yorumlanmak üzere gözlemlenmektedir. ${ }^{80}$

74 Tarquinius Superbus, Roma’nın İÖ 535-510 yılları arasında tahtta kalan son kralıdır.

75 Çiğdem Dürüşken, Roma ’nın Gizem Dinleri, (İstanbul: Arkeoloji ve Sanat Yayınları, 2000), 30.

76 Duygu Tanrıver, Apollon Klaros Kültü, Kehanet Pratikleri ve Adaklar, Yayımlanmamış Doktora Tezi, (İzmir: Ege Üniversitesi Sosyal Bilimler Enstitüsü Arkeoloji Anabilim Dalı, 2009), 340.

77 Çiğdem Dürüşken, Roma 'nın Gizem Dinleri, 22.

78 'Gerçekten de kâhinlik Dodona'da ve Mısır'daki Thebai'de birbirine çok benzer. Geleceği kurbanın bağırsaklarına bakıp söylemek Mısır'dan alınmıştır. Dinsel törenler, alaylar, toplu halde dualar Misırlılarda başlamış, Hellenler onlardan almışlardır. Işste bence bir tanıt: Misırlıların yaptıkları törenler, gözle görülür surette bir daha eskilik markası taşırlar, Hellenler ise bunları pek yeni bir tarihten beri uygulamaktadırlar." Herodotos, Tarih, II. 58.

79 Bu duruma örnek olarak Euripides'in Elektra isimli eserinde önemli bilgiler bulunmaktadır: “Aigisthos, kutsal parçaları eline aldı ve onları dikkatle muayene etti. Karaciğerde bir parça lob eksikti, damarlar ve safra kesesi ise uğursuz çıkıntılar gösteriyordu." Bkz. Euripides, Elektra, Trans. Edward P. Coleridge, (New York: Random House, 1938), 826-829. Kehanet elde etmek amacıyla kurban edilen hayvanın ciğerlerinde lobun eksikliğinin olumsuz olarak yorumlanmasına dair Ksenophon'un da aktarımları bulunmaktadır. Sparta Kralı Agesilaos, savaş sırasında bir sonraki adımına dair tanrılara başvurmuştur. Bu başvuruda aracılık eden kurbanın ciğerinde bir lobun eksik çıkması ile birlikte bu durum olumsuz olarak yorumlanmış, yönünü denize doğru seçmiştir. Bkz. Ksenophon, Yunan Tarihi (Hellenika), Çev. Suat Sinanoğlu, (Ankara: Türk Tarih Kurumu Basımevi, 1999), III. 15.

80 Ayşen Sina, Antik Yunan'da Ordu Kâhinleri, 197. 
Kehanet elde edilirken kurban ritüelinin her aşaması önem teşkil etmektedir. Kurban hayvanının kesileceği yere isteyerek gelip gelmediği, ölümünün hızı, kuyruğunun hareketleri gibi tüm detaylar işaret olarak kabul edilmektedir. ${ }^{81}$

\subsubsection{Kuşlar Yoluyla Kehanet Alma}

Kurban dışında kehanete ulaşmak için kullanılan ana yöntemlerden biri de özellikle kartal ve akbabalar olmak üzere kuşların gözlemlenmesidir. Kuşların uçuşlarını gözlemleyerek yorumlayan kişilere augur (kuşbilici) denmektedir. ${ }^{82}$

Kuşların uçuşları incelenirken dikkat edilen durumlardan biri uçuş yönleridir. Kuzeye dönük şekilde sabit duran kâhinin sağından uçan kuşlar olumlu, solundan uçan kuşlar olumsuz işaret olarak yorumlanmaktadır. ${ }^{83}$ Kuşların gözlemlenmesi yoluyla kehanet elde edilirken kuşların uçuş yönleri dışında çeşitli olaylar da gözlemlenmektedir. Bu duruma örnek olarak Ksenophon’un bir kartal çığlığını kehanet olarak yorumlaması verilebilmektedir. ${ }^{84}$ Kehanet kuşlarından ayrıca Demeter'e hymnos ${ }^{85}$ ve Hermes'e hymnoslarda ${ }^{86}$ olmak üzere Homeros İlahileri'nde ve Homeros'un Odysseia ${ }^{87}$ eserinde de bahsedilmektedir.

\subsubsection{Rüya Yoluyla Kehanet Alma}

Kehanete dair bilgi sahibi olmak amacıyla rüya aracılı̆̆ını kullanmak bir diğer önemli yöntemi teşkil etmektedir. Rüya aracılığıyla kehanete ulaşmak üzere kullanılan malzemeler ile büyülerde yer alan tanrı ya da tanrıçalara bakıldığında Hellen ve Mısır'a dair uygulamaların birleşik bir yapıda olduğu görülebilmektedir. Daimon ${ }^{88}$ ve zeytin dalları ile birlikte Mısır'ın yerli bitkileri kullanılırken aynı zamanda Apollon ve Hermes ile birlikte Ra, Thoth, Isis gibi Mısır'a özgü tanrılar da kullanım görmektedir.

Duygu Tanrıver, Apollon Klaros Kültü, Kehanet Pratikleri ve Adaklar, 346.

82 Çiğdem Dürüşken, Roma'nın Gizem Dinleri, 22.

83 Walter Burkert, Greek Religion, 112.

84 "Karar vermekte zorlandığı için en iyisinin tanrılara danışmak olacă̆ını düşündü ve sonra iki kurbanlık getirip kendisine Delphoi'daki kehanette adı bahşedilen kral Zeus'a kurban etti. Zaten ordunun ortak idaresi sürecinde yer almak için harekete geçtiği sırada gördüğü rüyanın da kendisine bu tanrı tarafindan bahşedildiğini düşünüyordu. Sonra Kyros'a takdim edilmek üzere Ephesos 'tan yola çıktı̆̆ında să̆ tarafında oturan bir kartalın çı̆̆lık attığını hatırladı. Kendisine yol gösteren kâhin bunun sıradan değil, büyük bir olayın; şan ve şerefin yanında bir o kadar da zahmetin habercisi olduğunu söylemişti. Çünkü diğer kuşların kartala çoğu zaman tünemişken saldırdığını ifade etmişti. Öte yandan kâhin kehanetin bir servete işaret etmediğini, çünkü kartalın avını genellikle uçarken yakaladığını belirtmişti. Ksenophon bu düşüncelerle kurban kesince tanrı ona açıkça komutanlı̆̆a heveslenmemesini, seçilmesi halinde de bunu kabul etmemesini belirtti.” Bkz. Ksenophon, Anabasis, VI. 1. 23.

85 Homeros İlahileri. Çev. Ayşen Sina, (İstanbul: Arkeoloji ve Sanat Yayınları, 2008) II. 44-48.

86 The Homeric Hymns and Homerica, IV. 212-215. Ayrica bkz. The Homeric Hymns and Homerica, IV. 300-303.

87 Homeros, Odysseia. XV. 525-535.

88 Daimonlar tanrı ya da tanrıçaların emirlerini yeryüzünde yerine getirmekle yükümlü elçi görevinde kutsal varlıklardır. Bkz. Geraldine Pinch, Magic in Ancient Egypt. (London: British Museum Press, 1994), 35-36. 
Kehanete ulaşmak adına uygulanmak üzere yazılmış büyü metinlerinden birinde Apollon'a nelerin danışılabileceğinin içerisinde rüya yorumu da yer almaktadır: "Ve o geldiğinde, kehanet sanatı, epik dörtlüklü kehanet, rüyaların gönderilmesi, rüyada öngörü edinme, rüyaların yorumu, hastallğa sebep olma ve büyüsel bilgi ile alakalı istediğin her şeyi sor." ${ }^{89}$

Kutsal varlıkların isimlerinin yazılması ve büyülü formüller dışında Mısır büyü külttüründe de varlığı bilinen kandillerin kullanımı kehanet büyülerinde de görülmektedir. Rüya aracılığıyla kehanete ulaşmanın amaçlandığı ve kandil ile birlikte zeytin dallarının da yer aldığı bir büyü metninde Apollon'un bu kez üçayaklı sehpası da yer almaktadır. Büyülü sözler okunurken yerden toplanılan üç sazdan sonuncusu kehanetin amacı söylenirken alınmalıdır. Ritüeli yerine getiren büyücü isteklerini söylerken yedi madde şeklinde büyülü sözler mürekkep ile yazılır. Kırmızı renkte olmayan ve yağ ile doldurulmuş kandile doğru büyülü kelimeler söylenir. Bu sırada kandil doğuya doğru döndürülmüş olmalıdır. Topak şekline gelmiş buhurlar tütsü kabına konur ve toplanılan sazlardan üçayak şekli oluşturulur. Bu sazlardan bir tanesinin başına taç şekline getirilmiş zeytin dalı konur. Büyü uygulamasının sonunda ise düz bir zeminde ve ş̧ıksız bir ortamda uyuyan kişinin, kendi gözünden Apollon'u görebilmesi amaçlanmaktadır. ${ }^{90}$

Rüyada kehanete ulaşma amacıyla gerçekleştirilen başka bir büyü metninde ise klasik sayılabilecek malzemelerden farklı olarak burç kuşaklarının kullanıldığı görülmektedir. Kişinin tanıdığı bir arkadaşı şekline girmiş olan güneşe bağlı bir meleği rüyada görmek amaçlanmaktadır. Büyünün uygulanış biçiminde ise defne dalının her bir yaprağına Zodyak burç kuşağı yanında kutsal isimlerin yazılması istenmektedir. ${ }^{11}$

Bir başka rüyada kehanet elde etmek için uygulanan büyü ritüelinde bu kez formül kullanımı da görülmektedir. Temiz bir keten şerite "HARMIOUTH LAILAM CHŌOUCH ARSENOPHRĒ PHRĒU PHTHA HARCHENTECHTHA" formülünün yazılması istenilmektedir. Formül yazımının ardından keten şerit fitil şekline getirilmek üzere yuvarlanılır. Akşam vakti geldiğinde uyku aşamasına geçilmeden önce kandilin yanında formül yedi kez seslendirilir. Kandil söndürülür ve kehanete ulaşmak üzere uykuya gidilmektedir. ${ }^{92}$

Uyku sırasında kehanete ulaşmak amacıyla uygulanan büyü ritüelleri sırasında değişmez ön koşul, kişinin temiz ve saf bir şekilde uykuya geçmesidir. Temizlik ve saflık hali, tapınaklar yanında büyüler için de geçerli bir şarttır. ${ }^{93}$

\subsection{Antik Hellen ve Roma Toplumlarında Kehanet Merkezleri}

Tanrı ya da tanrıçaların yaşam alanlarının yeryüzüne bir yansıması olarak nitelendirilen

89 PGM I. 262-347.

90 Christopher A. Faraone and Dirk Obbink, Magika Hiera Ancient Greek Magic and Religion, (New York: Oxford University Press, 1991), 177-178.

91 PGM VII. 795-845.

92 PGM VII. 359-69.

93 Marcello Carastro, Tanrıların Dünyadaki Varlığı: Yunanistan'da Kült, Çev. Leyla Tonguç Basmacı, Ed. Umberto Eco, Antik Yunan, (İstanbul: Alfa Basım Yayım Dağıtım, 2018), 597. 
tapınaklar, insanlar ve tanrılar ya da tanrıçalar arasındaki iletişım alanı olmanın yanında toplulukların örgütlenme alanları olarak da nitelendirilmektedir. "Tapınak" denilen kutsal mekânların ortaya çıkışı, büyü formüllerinin ve ritüellerinin artışı ile paralel olarak değerlendirilmektedir. Sistemli bir hale ihtiyaç duyan ritüeller ile tapınakların gelişimi eş zamanlı meydana gelmektedir. Kutsal mekân olarak nitelendirilen tapınaklar mutlaka mimari bir yapı olmak zorunda değillerdir. Bir taş ya da ağaç olması görevini yerine getirmesine engel bir durum teşkil etmemektedir. Tapınakların varlığ dışında büyücüler, tablet kâtipleri, hekimler ve ritüel rahipleri tapınak görevlileri arasındadır. ${ }^{94}$

Kehanet merkezleri olarak bilinen tapınakların çoğu su kaynakları ve gaz kaynaklarının yakınlarında yer almaktadırlar. Özellikle gazlar kehanette önemli bir noktayı teşkil etmektedir. ${ }^{95}$ Su kaynakları ise toprak ana inancıyla ilişkili olarak değerlendirilmektedir. Suyun akıcılığı ile birlikte insanlara hastalıkların yanı sıra armağanların da gönderildiğine dair inanış bulunmaktadır. Hellen hikâyelerindeki suyun rolü nedeniyle insan ve doğanın doğurganlığı ile toprak anayla özdeşleştirilmesi, su kaynakları ve kehanet merkezleri arasındaki ilişkiyi de açıklamaktadır. ${ }^{96}$

Çalışma ile ilgili olarak Sura, Gryneion, Patara, Smintheion ve Erythrai gibi önemli kehanet merkezlerinin dışında en önemlilerinden sayılabilecek Klaros, Delphoi ve Didyma'ya dair açıklamalarda bulunmak yerinde olacaktır.

\subsubsection{Klaros ve Kehanet}

Günümüz İzmir'inin Menderes ilçesi içerisinde bulunan Klaros kutsal alanı ve kuruluşu ile ilgili Pausanias'ın çeşitli aktarımları bulunmaktadır. ${ }^{97}$ Hemen hemen tüm arkeolojik bilgi ve buluntuları Hellenistik ve Roma dönemlerine denk gelen Klaros Kehanet Merkezi’ne Büyük

94 Kürşat Demirci, Eski Mezopotamya Dinlerine Giriş, Tanrı, Ritüel, Tapınak, (İstanbul: Ayışı̆̆ı Kitapları, 2013), 79-83.

95 Eusebios gazlarla ilgili şu aktarımda bulunmuştur: "Söz konusu Klaros ve Pythios Kutsal Alanları'nın olduğu yerlerde Phoibos konuşur. Bizim cümlelerimiz kehanet diliyle verilecektir. Sayısı kehanetler toprak üzerine ya kaynayan gazlarla ya su kaynaklarıyla ya da rüzgâr anaforlarıyla çıkacaklardır. Toprak bizzat kendisi açılıp birilerini yer altındaki karanlıklara aldı. Buna karşın bazıları sonsuzluk içinde yok edildiler. Sadece güneş ölümlüler için parlar. Hala Mykale'deki Didyma tanrısının suyu boğazlardan geçer (içilir). Parnassos Dă̆ı'nın altındaki Pythios'un kenarında koşan da bu tanrıdır (Apollon). Aynı şekilde Klaros'un bozuk, çakıllı, düzensiz ă̆zında Phoibos'un sesi yükselir.” Bkz. Duygu Tanrıver, Apollon Klaros Kültü, Kehanet Pratikleri ve Adaklar, 557. Ayrica bkz. Eusebios, Praeparatio Evangelica, Trans. Ruth Pearse, (UK: Ipswich, 1903), V.16.1.

96 William Reginald Halliday, Greek Divination: a Study of its Methods and Principles. (London: Macmillan, 1913), $122-123$.

97 “Kolophon halkı Klaros 'taki kutsal alanın ve kehanet merkezinin çok eski zamanlarda kurulduğuna inanırlar. Onlar şunu iddia ederler: Topraklara Karialılar hakimken, ilk gelen Hellenler büyük bir kalabalık tarafindan takip edilen Rhakios önderliğindeki Giritlilerdi. Güçlü gemilere sahip olan bu işgalciler sahili ele geçirdiler. Ancak, arazinin çoğu hala Karların elindeydi. Polyneikes oğlu Thersandros ve Argoslular Thebai'i ele geçirdiklerinde, Delphoi'a getirilen esirler arasında Manto da vardl. Babası Teiresias yolda, Haliartia'da öldü. Tanrı onları bir koloni kurmak için gönderdiği zaman, Asia'ya gemilerle geçtiler. Fakat Klaros'a geldiklerinde Giritliler onları silahlarla karşıladılar ve onları Rhakios'a götürdüler. O ise Manto 'dan onların kim olduklarını ve neden buraya geldiklerini ögrenince Manto'yu eş olarak aldı ve onunla birlikte olanların da bu topraklara yerleşmelerine izin verdi. Rhokios ve Manto'nun oğlu olan Mopsos, Karları tamamen ülkeden dişarı attı...” Bkz. Pausanias, Description of Greece. Trans. W. H. S. Jones, (Cambridge: Harvard University Press, 1918), VII. 3. 1-4. Ayrıca bkz. Duygu Tanrıver, Apollon Klaros Kültü, Kehanet Pratikleri ve Adaklar, 536-538. 
İskender ile başlayan ve sonraları sürekli şekilde devam eden bireysel başvuruların varlığı bilinmektedir. ${ }^{98}$

Pausanias'n Klaros Kehanet Merkezi'ne dair aktarımlarından biri de kehanetin gerçekleştirilme zamanlarına dairdir. Buna göre Hekate-Artemis'e adanmış günlerde ya da bu günlerin hemen öncesinde gerçekleştirilen kehanet ritüeli kâhinin kutsal su aracılı̆̆ıyla orucunu bozması ve yüzünü yıkaması ile başlamaktadır. Kehanete dair bilgileri elde eden kâhin bu yanıtları rahibe, rahip de heksametron vezine çevirerek başvuru sahiplerine iletmektedir. ${ }^{99}$ Her zaman gece vakitlerinde gerçekleştirilen kehanet ritüelini bir mağarada ya da yer altı odasında kutsal sudan içerek başlatan kâhin her yıl değişirken, yanıtları başvuranlara ileten rahipler ömür boyunca görevlerine devam etmektedirler. ${ }^{100}$

\subsubsection{Delphoi ve Kehanet}

Yerleşimi Mykenai Dönemi'ne dek uzanan ve Parnassos Dağları'nın eteklerinde yer alan kentin insanları Gaia'ya ${ }^{101}$ taparlarken Apollon tapınımının kente girmesi büyük değişimlere de sebep olmuştur. Delphoi ve Apollon ilişkisinin başlangıcına dair iki farklı mitos bulunmaktadır. İlk mitosa göre Delphoi'da canlıları öldüren canavar olarak bilinen Python'u öldüren Apollon'un burada tapınak kurmayı istemesiyle ilgilidir. Python'un ölümü sonrasında Gaia'nın ikinci planda kalması ile kehanetler artık Pythia aracılığıyla bildirilmektedir. Bir diğer mitos ise Zeus'un dünyanın iki ucundan kartal uçurmasıyla başlamaktadır. Kartalların Delphoi'a gelmesi orta nokta olmasına dair bir işaret olarak anlaş1 lmıştır. ${ }^{102}$

Delphoi Tapınağı içerisinde bulunan ve "dünyanın göbeği" olarak bilinen bir çukur üstüne yerleştirilmiş üçayaklı sehpa aracılığıyla kehanetlere ulaşılmaktadır. Apollon'un kâhin kadınlarından biri olan Pythia'nın sehpaya oturduktan sonra bu çukurdan gelen gazlarla birlikte transa geçerek kehanette bulunduğu söylenmektedir. ${ }^{103}$

Kehanet ritüelleri Delphoi'da yılda yalnızca bir kez gerçekleştirilirken, ününün ve taleplerin artması sonucunda kışı kapsayan üç ay dışında her ayın yedinci günü yapılmaya devam edilmiştir. Pythia, Kastalia Irmağı'nda yıkanarak ritüele hazırlanırken kurban edilecek hayvan rahip tarafından hazırlanmaktadır. Kurban hayvanının kesiminden sonra tekrar arınma ritüeli gerçekleştirilmektedir. Son olarak kutsal odada gaz soluyarak ve kutsal sudan içerek kehaneti elde eden Pythia, cevapları rahibe iletmektedir. Rahip de kehaneti heksametron vezin biçiminde danışanlara iletmektedir. ${ }^{104}$

98 Nuran Şahin, Apollon Klarios Bilicilik Merkezi, Ege Üniversitesi Arkeoloji Kazıları, (İzmir: Ege Üniversitesi, 2012 ), 325.

99 Nuran Şahin, Apollon Klarios Bilicilik Merkezi, 327-328.

100 Ekrem Akurgal, Anadolu Uygarlıkları, (İstanbul: Net Turistik Yayınları, 2003), 314.

101 Zamanla içinden tanrısal soyların doğacağı ilk öğe olarak bilinen Gaia, bir çok kâhinin esin kaynağıdır. Kâhinleri ise Apollon'un kâhinlerine göre çok daha eskiye dayanmaktadır. Bkz. Pierre Grimal, Mitoloji Sözlüğ̈̈, 203-205.

102 Michael Maßß, Delphi: Kehanet Merkezi. Aktüel Arkeoloji Dergisi, c. 22, (2011), 109-111. Ayrıca bkz. Pierre Grimal, Mitoloji Sözlüğ̈̈, 677-678.

103 Azra Erhat, Mitoloji Sözlüğ̈̈, 49. Ayrıca bkz. Charles Freeman, Misır, Yunan ve Roma, 228.

104 Bekircan Tahberer, Antik Tarsos Numismatiğinde Apollo, Lykeios mu, Yoksa Patroos mu?. Yazılı bildiri, Uluslararası Türk Dünyası İnanç Merkezleri Kongresi Bildirileri, (Mersin, 2002, Eylül), 1116. 
Arkadia'yı ele geçirme isteği içerisinde bulunan Spartalıların Delphoi'a danışmas ${ }^{105}$ örneği gibi Delphoi Kehanet Merkezi, savaş ve siyasette de önemli rollerde bulunmaktadır. ${ }^{106}$ Kehanet Merkezi'ne dair Herodotos'un dışında Platon'un çeşitli aktarımları mevcuttur. ${ }^{107}$

Delphoi'a Hellenlerin başvuruları dışında Romalıların da sık sık başvuruda bulundukları bilinmektedir. Hannibal karşısında üst üste yenilgiye uğrayan ve tanrılarının kendilerini terk ettiğine dair düşünceye kapılan Romalılar, yol gösterilmesi ve tekrar güven kazanılması amacıyla Delphoi Kehanet Merkezi'ne başvurmuşlardır. Korku ve tedirginlikleri öyle bir hâl almıştır ki tanrılar için Gallialı ve Hellaslı bir çifti diri diri yakarak kurban etmişlerdir. ${ }^{108}$

Delphoi Kehanet Merkezi tüm bu başvuru sebeplerinin yanında koloni süreçlerinde de varlığını göstermektedir. Koloni kurma hazırlığında olan kent batıya gitmeyi amaçlıyorsa Apollon'un tavsiyelerini almak üzere Delphoi'a danışmaktadır. Delphoi'dan gelen yorumlar koloniciler için belirleyici bir rol oynamıştır. ${ }^{109}$

\subsubsection{Didyma ve Kehanet}

Ionia'nın en büyük kenti Miletos'un kurduğu Apollon Didyma Tapınağı'nın kuruluşunun Ionlar zamanına dek uzandığını Herodotos belirtmektedir. ${ }^{110}$ Pausanias ise tapınağın Ionialıların göçünden daha da erken vakitlere dayandığını söylemiştir. ${ }^{111}$ Tapınağın kalıntıları ise İÖ 4. yüzyıla, Geç Klasik Dönem'e dek uzanmaktadır. ${ }^{12}$

105 “...Arkadialılardan daha güçlü olmakla övünmeye başladılar, 'Bütün Arkadia'yı ele geçirebilir miyiz?' diye kehanete danıştılar. Pythia onlara aşağıdaki kehaneti söyledi...” Bkz. Herodotos, Tarih, I. 66. Ayrıca Tegealılara karşı üst üste başarısızlıklarla karşılaşan Spartalılar Delphoi’a tekrar başvurmuş, hangi tanrıları mutlu etmeleri gerektiğini Pythia'ya sormuşlardır. Bkz. Herodotos, Tarih, I. 67.

106 Herodotos'un aktarımlarına göre İÖ 480 yılında Kserkses'in Hellas'a saldırısından önce, Perslere teslim olma konusunda emin olamayan Argosluların Delphoi'dan gelen kehanet sonucunda tarafsız durumlarını sürdürdükleri bilinmektedir. Bkz. Herodotos, Tarih, VII. 148. Ayrıca Yine aynı yılda Pers tehlikesi baş gösterdiğinde Atinalılar Delphoi’a başvurmuşlardır. Bkz. Herodotos, Tarih, VII. 140. Bir başka örnek ise Hellenlerin daveti üzerine savaş girmek üzere olan Giritlilerin Delphoi danışmanlığında hareket etmeleri üzerinedir. Bkz. Herodotos, Tarih, VII. 169.

107 “Atinalı: Öyleyse, birçok çaba ve tehlikede birbirlerine destek oldukları için bu durumun kalıcı olacağına ve uzun bir süre yaşayacă̆ına, kralları kardeş olduğuna göre hep aynı soy tarafindan yönetileceklerine inanıyorlardı, ayrıca birçok kehanete, bunların yanı sıra Delphoi'daki Apollon'a danışıyorlardı, değil mi?" Bkz. Platon, Yasalar, III. 686. Platon'un Delphoi'a dair farklı bir aktarımı ise şu şekildedir: "İlk kanunları, en önemli, en güzel olanları koymak Apollon'un işidir. Tapınakların kuruluşu; kurbanlar; büyük küçük tanrllara, kahramanlara yapılan törenler; ölülerin gömülmesi, saygl görmesiyle ilgili kanunlar; çünkü bu türlü işleri biz bilmeyiz. Bir devlet kurarken, aklımız varsa, biz de atalarımızın başvurduğu varliğa başvurur, yalnız onun sözünü dinleriz. Dünyanın göbeğinde oturan tanrı, hiç şüphesiz atalarımıza ve bütün insanlara yol gösteren tanrıdır." Bkz. Platon, Yasalar, IV. 427.

108 Charles Freeman, Misir, Yunan ve Roma, 376-377.

109 Walter Burkert, Greek Religion, 116.

110 ...Kymeliler Brankhosoğullarının tanrısına danışmaya karar verdiler. Orada bir kehanet alanı vardı, eski zamanlarda kurulmuştu ve bütün Ionlar ve Aiollar öteden beri hep ona danışırlardl. Miletos toprağ üzerinde Panormos Limanı'nın ötesindeydi." Bkz. Herodotos, Tarih, I. 157.

111 Pausanias, Description of Greece, 7. 2. 6.

112 Andreas Furtwängler, Didyma Brankhid Kahinleri. Aktüel Arkeoloji Dergisi, c. 22, (2011), 66. 
Delphoi ve Klaros ile benzer olarak kehanet merkezinde kâhine eşlik eden ve görevi muhtemelen danışmaya gelenleri karşılamak ve kehaneti aktarmak olan rahip (prophetes) bulunmaktadır. Delphoi'dan farklı olarak ise Didymalı rahipler, kehanet yazıtlarını Didyma veya Miletos'ta dikerek saklanmasına ayrı bir önem vermektedirler. ${ }^{113}$

Herodotos'un aktarımına göre zenginlik bakımından Delphoi Kehanet Merkezi ile rakip durumuna gelen Didyma'nın maddi durumu öylesine iyiydi ki Miletos, Pers savaşı öncesinde Didyma'daki hazinelerin yardımıyla bir donanma kurmayı düşünmüştür. Savaş sonunda Miletos'un Persler tarafından ele geçirilmesi ${ }^{14}$ sonucunda Didyma da yağmalanmıştır.

Didyma Kehanet Merkezi'ne çeşitli amaçlarla danışmak isteyenler gelmektedir. Bunların içerisinde Atina' da İÖ 451 yılında kabul edilen yasadan dolayı yabancı bir kentten gelerek vatandaşlık almak isteyen birinin kehanete başvurma zorunluluğundan dolayı gelmesi ${ }^{115}$, Lydialı Paktysas'ın, Kyros'a karşı başarısız bir ayaklanma gerçekleştirmesinden sonra kaçtığı Kyme'nin kararsız kalması ve bu doğrultuda Didyma'ya başvurması gibi çeşitli alanlara ait örnekler bulunmaktadır. ${ }^{116}$ İS 130 yıllarında İskenderiyeli sporcu Apphion Heronas'ın da şu soruyla danıştı̆̆ı bilinmektedir: "Atalarının tanrıları ve sen ona her girişiminde destek olduğunuz için şimdi size soruyor efendim, bu yarışmalardan da her zamanki gibi şerefli bir biçimde çıkacak mı?" Gelen yanıtta ise tanrıların anılması açıkça görülmektedir: "Phoibos, Serapis ve atletlerin yarışmalarını gözeten Nemesis'e dua et, o zaman istediğin gibi yardımına koşacaklardır."117

\section{KEHANET BÜYÜLERINIIN BILEŞENLERİ}

\subsection{Kehanet Büyülerinde İsmi Geçen Tanrı ve Tanrıçalar}

Hellen tanrı ve tanrıçaları, mitoslarına da bağlı olarak bazı kültürel etiketleri ile birlikte bilinmektedirler. Hera için evlilik tanrıçası, Aphrodite için aşk tanrıçası, Poseidon için deniz tanrısı, Athena için bilgelik tanrıçası gibi etiketler kullanılmaktadır. Fakat tanrı ya da tanrıçaları bu şekilde sınırlandırmak tanrısal güçlerini de basite indirgeyeceğinden dolayı yanlış bir yöntem olacaktır. ${ }^{118}$ Dolayısıyla kehanet büyüleri sırasında Apollon dışında başvurulan tanrı ve tanrıçalara rastlanılması mümkündür. Büyü papirüslerinin Mısır bölgesine ait olmasından dolayı Hellen tanrı ve tanrıçaları

\footnotetext{
113 Andreas Furtwängler, Didyma Brankhid Kahinleri, 78.

114 Aristagoras liderliğinde Perslere karşı gerçekleştirilen isyan sonucunda Kserkses'in saldırısı meydana gelmiştir. İsyan sonrası Ionia şehirleri ağır vergilerle karşı karşıya kalmışlardır. Ionia isyanları ve Herodotos'un aktarımlarına dair daha ayrıntılı bilgiler için bkz. J. A. S. Evans, Herodotos ve Ionia İsyanı. Çev. Ömer Çapar, Tarih Araştırmaları Dergisi, c. XIII, (1980), 88.

115 Tesamenos isimli bir kâhinin Delphoi kehanetleri sonucunda vatandaşlığa alındığı bilinmektedir. Bkz. Herodotos, Tarih, IX. 33-36.

116 Herodotos, Tarih, I. 157-160.

117 Duygu Tanrıver, Apollon Klaros Kültü, Kehanet Pratikleri ve Adaklar, 376-377.

118 Gabriella Pironti, Yunanların Tanrıları ve Tanrıçaları, Çev. Leyla Tonguç Basmac1, Ed. Umberto Eco, Antik Yunan, (İstanbul: Alfa Basım Yayım Dağıtım, 2018), 555-557.
} 
ile Mısır kültürüne ait kutsal isimlerin senkretik bir yapıda yer aldıkları da görülmektedir. Büyü papirüslerinde yer alan tanrı ve tanrıçalardan çeşitli büyü örnekleri ile bahsetmek yararlı olacaktır.

\subsubsection{Anubis}

Cesetlerin mumyalanması ve mezarların korunması ile ilişki içinde gösterilen Tanrı Anubis, genellikle vahşi bir köpek kafası ile birlikte tasvir edilmektedir. Anubis'in epitetleri de ölülerin yargılanmasında ve mezarlara zarar verenleri cezalandırmasında etkin olmasından dolayı "kutsal toprakların efendisi”, "batılıların önde geleni” biçimlerinde yer almaktadır. Bu epitetler aynı zamanda ölülerin lideri olarak bilinmesiyle de ilişkilidir. Roma Dönemi’nde ise Anubis yine önemli bir mezar tanrısı olarak görülmektedir. Büyücüler ile olan ilişkisinden kaynaklı olması ihtimaliyle Latin yazarları tarafından kötü yorumlarla kullanım görmüştür. Bağlama gibi çoğunlukla kara büyülerde yer bulan Anubis, çağırılma aşamasında da vahşice uygulamaların kullanılması ile bilinmektedir. Bu uygulamalardan biri, büyücünün yanıtlara ulaşması için Anubis’i çağırırken siyah bir köpeğin kanı ile Anubis'in tasvirinin çizilmesidir. ${ }^{119}$

Kehanetin Anubis’ten istendiği bir büyü metni şu şekilde yer almaktadır:

“Bakır bir kap içine dökülen yağmur suyunu alın ve buhur haline getirin.

Formül: Bırakın dünya dursun, hava dursun, deniz dursun, rüzgâr dursun; bunlar benim kehanetime engel değildir. Sessiz, ağlamasız, tıslamasız. Çünkü ben bir kâhinim ve korkutucu bir isim çağırmak üzereyim 'KOLLA OLPHILOGEMALA ACHERŌIO'. Bana cevap vermeni istediğim şeyleri açıklayabilmen için kulaklarımı aç. Hadi hadi; hemen hemen; hızlı hızlı; ve sana sorduğum şeyler hakkında konuş. Bana görün efendim, Anubis, 'sana emrediyorum, çünkü ben IEŌ BELPHENŌ.

Bitirmek için şunu söyle: 'Uzaklaş Anubis, kendi tahtına doğru, sağlığım ve iyiliğim için.' Bu ritüeli kendinizi 3 gün süre boyunca saf ve temiz tuttuktan sonra uygulayın."120

\subsubsection{Apollon}

Zeus ile Leto'nun oğlu ve Artemis'in ikiz kardeşi olan Apollon, doğduğu Ortygia ya da Astaria olarak bilinen adayı Hellen dünyasının merkezi haline getirmiş ve adaya parlak anlamına gelen “Delos" ismini vermiştir. Daha önce bahsedildiği üzere buraya gelişinden sonra Python'u öldürmüş ve tapınağa kehanet ritüellerinde kullanılmak üzere üçayaklı sehpayı vakfetmiştir. ${ }^{121}$

Hellen inanç dünyasında büyük öneme sahip olan Apollon'un kutsal sembolleri arasında defne ağacı ve yapraklarından yapılan çelenk, yunus ve karga bulunmaktadır. Müzisyen kimliği

119 Geraldine Pinch, Handbook of Egyptian Mythology. (Santa Barbara: ABC-CLIO, 2002), 104-105.

120 PGM VII. 319-34.

121 Pierre Grimal, Mitoloji Sözlüğü, 71-72. 
ise Olympos tanrılarına ziyafetlerde çaldığı yedi telli altın lyra ile betimlenmektedir. ${ }^{122}$ Hymnosta şiir ve müzik ile ilişkisi tanrılara lyra ile eşlik etmesi ile aktarılmaktadır. ${ }^{123}$ Yine hymnosta tanıının kehanet ile ilişkisine "Önceden haber vereceğim Zeus'un niyetlerini insanlara kesin ve doğru biçimde" sözleri ile değinilmektedir. ${ }^{124}$

Kehanet ile ilişkisi Apollon'un aşk hayatında da ortaya çıkmaktadır. Apollon, kehanet sanatını Kassandra'y1 ${ }^{125}$ etkilemek için öğretmiştir. Fakat kehaneti tamamıla öğrenen Kassandra'nın kendini geri çekmesiyle birlikte Apollon, Kassandra'nın kehanetlerinin güvenilirliğini geri almıştır. ${ }^{126}$ Apollon'un bir başka kehanet sanatını öğrettiği hikâyede ise bu kez Hermes yer almaktadır. Hermes'in icat ettiği flütü satın almak isteyen Apollon karşılığında altın bir asa ile birlikte Hermes'e kehanet sanatını öğretmiştir. ${ }^{127}$

Kehanet büyü metinlerinde sıkça yer alan Apollon'a, sosyal yaşam ve devlet işleri dahil olmak üzere çeşitli konularda güvenceye sahip olmak ve belirsizlikleri çözmek adına danışılmıştır. ${ }^{128}$ Apollon bir büyü papirüsünde epitetleriyle birlikte yer almaktadır:

"Ey Phoibos, kehanetleri ile yardım eden,

Gel neşeli, Leto'nun oğlu, uzakta çalışan,

Dönüştürücü, buraya gel, buraya, buraya gel.

Kehanet ver, gece saatinin ortasında kehanet ver." 129

Büyü metninin devamında ise Leto ve Zeus'un oğlu olduğu vurgulanarak devam edilmiştir:

“...̇̇yi kehanetin kelimeleri

Doğru kehanetlerle şimdi yolunu açabilirsin,

LAĒTONION ve TABARAŌTH AEŌ EŌ, Efendi Apollon, bu geceyi kontrol eden, bunda usta olan, duanın da saatini tutan. Gel, kudretli ruhlar, bana bugün yardım edin, Leto ve Zeus'un oğluyla gerçekten konuşarak." 130

122 Bekircan Tahberer, Antik Tarsos Numismatiğinde Apollo, Lykeios mu, Yoksa Patroos mu?, 1113.

123 The Homeric Hymns and Homerica. IIIb. 200-205.

124 The Homeric Hymns and Homerica. IIIa. 130-135.

125 Priamos ile Hekabe'nin kızı olan Kassandra, Sibyll ya da Pythia gibi kâhin olarak anılmaktadır. Paris'in gelişinin Troia'da büyük yıkıma sebep olacağına, Priamos'un Akhilleus'tan oğlunun cesedini alarak döneceğine ve şehrin girişine bırakılan tahta atın içeri alınmaması gerektiğine dair önemli konularda kehanetleri bulunmaktadır. Bkz. Pierre Grimal, Mitoloji Sözlüğü, 356.

126 Pierre Grimal, Mitoloji Sözlüğ̈̈, 73-74.

127 Pierre Grimal, Mitoloji Sözlüğ̈̈, 74.

128 Selin Kaddar, Tanrıların En Yunanı Apollon: Kehanet ve Şifa. Toplumsal Tarih Dergisi, c. 266, (2016), 88.

129 PGM II. 1-64.

130 PGM II. 1-64. 


\subsubsection{Helios}

Titan Hyperion ile Theia'nın oğlu olan ve kuşağından dolayı Olymposlulardan önce gelen Helios, Selene'nin kardeşidir. Gaia ile Ouranos'un soyundan gelmektedir. Helios'un çocuğu ise büyücü Kirke, Kolkhis Kralı Aietes, Minos’un karısı Pasiphae ve kardeşi Aietes'i tahttan indiren ve Medea tarafından öldürülen Perseus'tur. Helios, başının etrafinda 1şık hüzmeleri olan yakışıklı bir genç adam olarak tasvir edilmektedir. ${ }^{131}$

Betimlemeleri ile birlikte anıldığg bir daimon çağırma büyüsünde Helios’a epitetleri yanında kehaneti seven özelliği ile seslenilmektedir:

“Gel bana, cennetin en yücesi, cennetin bir dans yeri olduğu kişi, / SATIS ${ }^{132}$ PEPHŌOUTH HŌRA, OITHCHOU; benim için gerekli olanı uygula, EI LAANCHYCH AKARBĒN LAAR MENTHRĒ SENEBECHYCH, kehaneti seven, altın yüzlü, 1şık saçan altın parlayan / gecede ateşle parlayan, cesur, dünyanın cesur hükümdarı, günün erken saatlerinde parlayan..."133

Gün doğumunda yapılması istenen bir başka büyüde Helios "altın saçlı” betimlemesiyle tekrar kendini göstermektedir:

"Rüzgarların üzerinde doğan,

Altın saçlı Helios, alevleri kullanan,

Yüce yollarda dönüp duran, büyük kutbun çevresinde

Kendi kendine her şeyi yaratan..."134

Mitolojik özellikleri ile birlikte Helios'un anıldı̆̆ı bu büyü metninde Misır inanç kültüründen bir tanrının bulunması, Mısır'da güneş kültüne karşı büyük bir ilginin bulunmasıyla açıklanabilmektedir. Bu doğrultuda Mısır'daki büyü metinlerinde Helios ile sıkça rastlanılmaktadır.

Bir kehanet büyüsünde formül ile birlikte Helios'a nelerin söylenmesi gerektiği bildirilmektedir: "Parmağını kimseyle konuşmadan önce dilinin altına koy. Kutsal isimleri ve şunları söyle: 'Bugün bana herkesin zihnindeki şeyler hakkında kehaneti ver. Ben TOM...

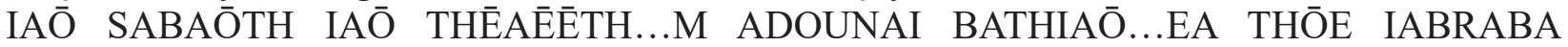
ARBATHRAS IAŌ THĒAĒĒTH...M ADOUNAI BATHIAŌ AĒI AAAAAAA EEEEEEE ... ŌE ... SOESĒSISIETH...SABAŌTH IAEŌ' Eğer bunları Helios'a söylersen ve parmağın dilinin

131 Pierre Grimal, Mitoloji Sözlüğü, 239-240.

132 Misir Tanris1.

133 PGM III. 130-140.

134 PGM IV. 435-440. 
altında ise her şeyi önceden bileceksin...”"135

Bir başka büyü metninde ise bu kez Yahudi-Hristiyan geleneklerinin de etkisiyle monoteizme olan yönelim açıkça görülmektedir. Helios bu kez "büyük güç", "büyük kudret", "tanrıların tanrısı" gibi sıfatlarla ortaya çıkmaktadır. ${ }^{136} \mathrm{Bu}$ sıfatlar ile birlikte görülüyor ki politeist tanrı ya da tanrıçaların diğer tüm tanrıların güçlerini tek elde toplaması ile birlikte monoteist biçimde büyü örnekleri ortaya çıkmaktadır. ${ }^{137}$

\subsubsection{Mithras}

Roma İmparatorluğu ile birlikte Britannia'dan Persia'ya dek uzanan ve oldukça geniş bir coğrafyada tapınım gören ve İran-Hint kökenli olan bir diğer önemli tanrı Mithras’tır. Zaman zaman kehanet büyülerinde de yer almaktadır.

Roma Dönemi'nin Önasya Bölgesi'nde sayıca az olsa da büyük öneme sahip büyü metinlerinde Mithras yer almaktadır. Çoğunlukla büyü metinlerinde Helios ile birlikte anılmaktadır. Bir büyü metninde Zeus ve Helios ile birlikte yer almaktadır: "Bir erkek çocuğu, kandil, fincan tabağı ve tezgah aracılığıyla gerçekleştirilen Sarapis'in Kehaneti: 'Seni çağırıyorum Zeus, Helios, Mithra, Sarapis, yenilmemiş olan, Melioukhos, Melikretes, Meligenetor..."138

Yine Helios ile birlikte anıldığı ve içerisinde boşlukların bulunduğu uzun bir büyü metninde ise şu şekilde yer almaktadır:

"Seni ve bir çocuğu bu yol çeker ... sonra, kuşların cıvıldama seslerini duyacaksın ... rezene ve susamın yedi tanesi, kimyon ... bunları al ve kaynak su aracılığıyla kır ... ikinci ay olduğunda her şeyi duyacaksın ...

... Ben IEE IOEE IE IAO ISI ... (insanların aklındaki şeyler) çünkü ben ... ona dua et. Ama ... / ...ama bu gelişin ezberlenmesi ... bu senin olan formülü yedi kez tekrar et ... formül: 'Gel Helios, Mithras ...' ... bu kutsal su ... onun zihninde olan ... / o gün bileceksin ... eğer ateşe dokunursan." 139

\section{Tartışma Sonuç}

İnsan, zorluklarla dolu yaşamda kendisini yardıma muhtaç hissetmesi nedeniyle sığınabileceği ve bu zorluklar karşısında kendisini yalnız hissettirmeyecek kutsal ve kendisinden üstün varlıklara ihtiyaç duymuştur. Bu ihtiyaç hali kutsal varlıkların doğuşunu teşkil etmiştir.

135 PGM III. 263-75.

136 PGM IV. 640-645.

137 Ahmet Türkan, Grek Büyü Papirüslerine Göre Roma İmparatorluğu Ortadoğusu’ndaki Yeni Din Anlayışı ve Kozmik Sistem Üzerine Bazı Gözlemler, Ed. Serra Durugönül, Murat Durukan, Gunnar Brands ve Deniz Kaplan, Olba, (Mersin: Kaam Yayınlar1, 2014), 319.

138 PGM V. 4-6.

139 PGM III. 450-465. 
Çalışmanın odağını oluşturan kehanet büyülerinin ortaya çıkışı ise arzu ve merak duygularıyla açıklanabilir. İnsan açlık ya da tokluk halinin devamını, gündelik işılerinin sonuçlarını, evlenip evlenmeyeceğini, daha büyük ölçekte ise devletinin savaşa girmesinin ya da girmemesinin nasıl sonuçlar doğuracağını bilmek ister. İnsanın bilmek istemesi ile ortaya çıkan merak duygusu kehanet büyülerine giden yolu açmaktadır. Bu durumu daha basite indirgemek gerekirse aslında insan, kutsal ve üstün gördüğü tanrı ya da tanrıçalarının bildiklerini bilmek istemektedir.

Bilginin gücüne sahip olmak isteyen insan tüm riskleri alarak bir yandan korkuyla çekindiği bir yandan da umutla tutunmaya çalıştığ kutsal varlıklarla yakınlaşmak istemektedir. Bu noktada önemli olan, tüm korkusuna rağmen insanın büyüler aracılığıyla kutsal varlıklarla iletişime geçme isteğidir. Fakat unutulmamalıdır ki kehanet büyülerinin sonucunda alınacak yanıt net biçimde olmayacaktır. Gelecek yanıt yoruma açık olarak elde edilecektir. Elde edilen kehanetler kesin bir sonuç bildirmemekle birlikte yalnızca tanrı ya da tanrıçaların onaylarının alınması üzerinedir.

Kutsal bir alana ait olmasından dolayı büyü eyleminin kendisi de kutsal olarak kabul edilmektedir. Büyünün amacına ulaşması için söylenilenlerin titizlikle ve eksiksiz yerine getirilmesi büyük önem teşkil etmektedir. Söylenen sözler, formüller ya da ilahiler, kullanılacak malzemeler, zaman ve yer gibi etmenler büyünün başarıyla sonuçlanması için titizlikle ayarlanmalıdır.

Çalışma süresince korku, merak ve arzu duygularıyla beslenerek varlığını sürdüren kehanet büyülerine papirolojik ve klasik kaynaklar eşliğinde değinilmiştir. Bunun yanında Antik Dönem yazarlarının aktarımları, toplumun genel bir kavram olarak büyü ve büyücülüğe bakış açısında dair fikir vermektedir. Genel düşünce olarak yasaklı ve zararlı olarak bilinen büyüler farklı dönemlerde de olsa hemen hemen toplumun her sınıfi tarafından kullanım görmüştür. Kehanet büyülerinin sonucunda elde edilen yanıtlar, bireylerin ve devletlerin atacakları her adımda belirleyici bir etken olarak bulunmuştur.

\section{Kaynakça}

Akurgal, Ekrem. Anadolu Uygarlıkları. İstanbul: Net Turistik Yayınları, 2003.

Apuleius. The Apologia and Florida of Apuleius of Madaura, Trans. by H. E. Butler, Oxford: Clarendon Press, 1909. 1985.

Burkert, Walter. Greek Religion, Trans. by John Raffan, Oxford: Blackwell Publishers,

Carastro, Marcello. Hareketlerden Sözlere Ritüel Temelli Adetler, Çev. Leyla Tonguç Basmacı, Ed. Umberto Eco, Antik Yunan içinde İstanbul: Alfa Basım Yayım Dağıtım, 2018.

Carastro, Marcello. Tanrıların Dünyadaki Varlığı: Yunanistan'da Kült. Çev. Leyla Tonguç Basmacı. Ed. Umberto Eco, Antik Yunan, İstanbul: Alfa Basım Yayım Dağıtım, 2018.

Carastro, Marcello. Yunanistan'da Büyünün İcadı, Çev. Leyla Tonguç Basmacı, Ed. Umberto Eco, Antik Yunan İstanbul: Alfa Basım Yayım Dağıtım, 2018. 
Catullus. The Carmina of Gaius Valerius Catullus, Trans. by Leonard Charles Smithers, London, 1894. 1923.

Cicero. De Divinatione. Trans. by William Armistead Falconer, Loeb Classical Library,

Cicero. Tanrıların Doğası. Çev. Çiğdem Menzilcioğlu, İstanbul: Kabalcı Yayınevi, 2012.

Cicero. Yasalar Üzerine. Çev. Cengiz Çevik, İstanbul: Türkiye İş Bankası Kültür Yayınları, 2016.

Clericuzio, Antonio. Yunanistan'da Büyü ve Kehanet. Çev. Leyla Tonguç Basmac1, Ed. Umberto Eco, Antik Yunan, İstanbul: Alfa Basım Yayım Dağıtım, 2018.

Demirci, Kürşat. Eski Mezopotamya Dinlerine Giriş, Tanrı, Ritüel, Tapınak, İstanbul: Ayışı̆̆ı Kitapları, 2013.

Dickie, Matthew W., Magic and Magicians in the Greco-Roman World. New York: Routledge 2003. 2005.

Durkheim, Emile. Dini Hayatın İlkel Biçimleri. Çev. Fuat Aydın, İstanbul: Ataç Yayınları,

Dürüşken, Çiğdem. Roma’nın Gizem Dinleri, İstanbul: Arkeoloji ve Sanat Yayınları, 2000.

Erhat, Azra. Mitoloji Sözlüğü, İstanbul: Remzi Kitapevi, 1996.

Euripides. Elektra, Trans. by Edward P. Coleridge, New York: Random House, 1938.

Euripides. Medea, Çev. Ari Çokona, İstanbul: Türkiye İş Bankası Kültür Yayınları, 2018.

Eusebios. Praeparatio Evangelica, Trans. by Ruth Pearse, UK: Ipswich, 1903.

Evans, J. A. S. Herodotos ve Ionia İsyanı. Çev. Ömer Çapar, Tarih Araştırmaları Dergisi, c. XIII, 1980.

Faraone, Christopher A. and Obbink, Dirk. Magika Hiera Ancient Greek Magic and Religion, New York: Oxford University Press, 1991.

Frazer, James George. Altındal II., Çev. Mehmet H. Doğan, İstanbul: Payel Yayınevi, 2012.

Freeman, Charles. Misır, Yunan ve Roma, Çev. Suat Kemal Ang1, Ankara: Dost Kitabevi Yayınlar1, 2003. 
Furtwängler, Andreas. Didyma Brankhid Kahinleri. Aktüel Arkeoloji Dergisi, c. 22, 2011.

Görkay, Kutalmış ve Kadığlu, Musa. Antik Yunan ve Roma Dönemlerinde Büyü ve Büyücülük. İstanbul: Elemterefiş, YKY, 2003.

Graf, Fritz. Magic in the Ancient World. Trans. by Franklin Philip, London: Harvard University Press, 1997.

Grimal, Pierre. Mitoloji Sözlüğü Yunan ve Roma, Çev. Sevgi Tamgüç, İstanbul: Kabalcı Yayınevi, 2012.

Halliday, William Reginald. Greek Divination: a Study of its Methods and Principles. London: Macmillan, 1913.

Herodotos. Tarih. Çev. Müntekim Ökmen, İstanbul: Remzi Kitapevi, 1973.

Hesiodos. Theogonia, Çev. Azra Erhat ve Sabahattin Eyüboğlu, İstanbul: Türkiye İş Bankası Kültür Yayınları, 2017.

Homeros İlahileri. Çev. Ayşen Sina. İstanbul: Arkeoloji ve Sanat Yayınları, 2008.

Homeros. Ilyada. Çev. Azra Erhat ve A. Kadir. İstanbul: Türkiye İş Bankası Kültür Yayınları, 2014.

Homeros. Odysseia, Çev. Azra Erhat ve A. Kadir. İstanbul: Türkiye İş Bankası Kültür Yayınlar1, 2014.

İznik, Erkan. "Magi, Magus ya da Magician: Rahipten Büyücüye”, Anadolu Üniversitesi Edebiyat Fakültesi Dergisi, c.1, s.3, 2005.

Kaddar, Selin. Tanrıların En Yunanı Apollon: Kehanet ve Şifa. Toplumsal Tarih Dergisi, c. $266,2016$.

Ksenophon. Anabasis, Çev. Oğuz Yarlıgaş, İstanbul: Kabalcı Yayınevi, 2011.

Ksenophon, Cyropedia, Trans. Walter Miller, Cambridge: Harvard University Press.

Ksenophon, Yunan Tarihi (Hellenika), Çev. Suat Sinanoğlu, Ankara: Türk Tarih Kurumu Basimevi, 1999.

Liddel and Scott, An Intermediate Greek-English Lexicon. New York: American Book Company, 1882. 
Maaß, Michael. Delphi: Kehanet Merkezi. Aktüel Arkeoloji Dergisi, c. 22, 2011. 2000 .

Malinowski, Bronislaw. Büyü, Bilim ve Din, Çev. Saadet Özkal. İstanbul: Kabalcı Yayınevi,

Marchant and Charles, F. Joseph. Cassell's Latin Dictionary: Latin-English and EnglishLatin, London: Cassell Company, 1952.

Pausanias. Description of Greece. Trans. by W. H. S. Jones, Cambridge: Harvard University Press, 1918.

Pinch, Geraldine. Handbook of Egyptian Mythology. Santa Barbara: ABC-CLIO, 2002.

Pinch, Geraldine. Magic in Ancient Egypt. London: British Museum Press, 1994.

Pironti, Gabriella. Yunanların Tanrıları ve Tanrıçaları, Çev. Leyla Tonguç Basmacı, Ed. Umberto Eco, Antik Yunan, İstanbul: Alfa Basım Yayım Dağıtım, 2018.

Platon. Devlet, Çev. Sabahattin Eyüboğlu ve M. Ali Cimcoz, İstanbul: Türkiye İş Bankası Kültür Yayınları, 2013.

Platon, Laches, Protagoras, Meno, Euthydemus, Trans. by Walter Rangeley Maitland Lamb, London: Harvard University Press, 1962.

Platon. Yasalar, Çev. Saffet Babür, İstanbul: Kabalcı Yayınları, 1998.

Preisendanz, Karl. Papyri Graecae Magicae (PGM). c. (I-II), 1928.

Sena, Cemil. Filozoflar Ansiklopedisi II, E-H. İstanbul: Remzi Kitabevi, 1975.

Sina, Ayşen. Antik Yunan’da Ordu Kâhinleri. Cedrus, c. VII, 2019.

Sophokles. Antigone, Çev. Ari Çokona, İstanbul: Türkiye İş Bankası Kültür Yayınları, 2017.

Sophokles. Kral Oidipus, Çev. Bedrettin Tuncel, İstanbul: Milli Eğitim Bakanlığı Yayınları, 1992.

Suetonius. On İki Caesar'ın Yaşamı, Çev. Fafo Telatar ve Gül Özaktürk, Ankara: Türk Tarih Kurumu Yayınları, 2008.

Şahin, Nuran. Apollon Klarios Bilicilik Merkezi. Ege Üniversitesi Arkeoloji Kazıları, İzmir: Ege Üniversitesi, 2012. 
Tahberer, Bekircan. Antik Tarsos Numismatiğinde Apollo, Lykeios mu, Yoksa Patroos mu?. Yazılı bildiri, Uluslararası Türk Dünyası İnanç Merkezleri Kongresi Bildirileri, Mersin. Eylül, 2002.

Tanrıver, Duygu. Apollon Klaros Kültü, Kehanet Pratikleri ve Adaklar, Yayımlanmamış Doktora Tezi, İzmir: Ege Üniversitesi Sosyal Bilimler Enstitüsü Arkeoloji Anabilim Dalı, 2009.

The Homeric Hymns and Homerica. Trans. by H. G. Evelyn and M. A. White, London: William Heinemann, 1920.

Thukydides. Peloponnesian War, Trans. Thomas Hobbes, London: Bohn, 1843.

Türkan, Ahmet. Grek Büyü Papirüslerine Göre Roma İmparatorluğu Ortadoğusu’ndaki Yeni Din Anlayışı ve Kozmik Sistem Üzerine Bazı Gözlemler, Ed. Serra Durugönül, Murat Durukan, Gunnar Brands ve Deniz Kaplan, Olba, Mersin: Kaam Yayınları, 2014.

Vergilius. Aeneis. Çev. Türkan Uzel, Ankara: Öteki Yayınevi, 1998. 